\title{
Regulatory Safety Issues in the Structural Design Criteria of ASME Section III Subsection NH and for Very High Temperatures for VHTR \& GEN IV
}

\section{Report}

by

William J. O'Donnell and Donald S. Griffin

\author{
Prepared for \\ ASME Standards Technology, LLC \\ Gen IV Materials Project \\ DE-FC07-05ID14712 \\ May 7, 2007 \\ Submitted to: \\ Jim Ramirez \\ Manager, Technology Development \\ ASME Standards Technology, LLC \\ Three Park Avenue \\ New York, NY 10016 USA \\ Phone: 212-591-8033 \\ Fax: 212-591-7196 \\ E-Mail: ramirezi@asme.org
}

O'Donnell Consulting Engineers, Inc.

2940 South Park Road

Bethel Park, PA 15102

Phone: 412-835-5007

Fax: 412-835-5017

E-Mail: wjo@odonnellconsulting.com 


\section{$\underline{\text { Table of Contents }}$}

May 7, 2007

\section{Section}

Page

1.0 Executive Summary 1

2.0 Introduction $\quad 5$

3.0 NRC and ACRS Safety Issues in Licensing Review of CRBR 5

3.1 Elevated Temperature Design and Operating Conditions 6

3.2 Structural Integrity Evaluation Approach for Licensing 7

3.21 Modes of Failure Considered $\quad 7$

3.22 Stress Categories $\quad 8$

3.23 Material Representation 8

3.3 Structural Integrity Evaluation Methods 9

3.31 Simplified Analysis Methods $\quad 9$

3.32 Detailed Analysis of Localized Areas 9

$\begin{array}{ll}3.33 \text { Models and Tests } & 10\end{array}$

3.4 Regulatory Safety Issues 10

$\begin{array}{ll}3.41 \text { Perspective } & 10\end{array}$

3.42 NRC Licensing Review 11

3.43 NRC Safety Concerns 12

3.5 Summary of CRBR Licensing Review 22

4.0 Current NRC Safety Issues for Structural Design of VHTR and 22 GEN IV Systems

4.1 Materials and Design Bases in ASME Code Case N-47, 22 NUREG/CR-5955, April 1993

4.2 Safety Evaluation of the Power Reactor Innovative Small 23 Module (Prism) Liquid-Metal Reactor

4.3 Materials Engineering Research Needs for Advanced 25 Reactors - ACRS, USNRC/RES, and ORNL

4.4 Review and Assessment of Codes and Procedures for HTGR 26 Components, NUREG/CR-6816 (ANL-02/36), June 2003

4.5 Materials Behavior in HTGR Environments, NUREG/CR-6824 28 (ANL-02/37), July 2003

4.6 Design Features and Technology Uncertainties for the Next 29 Generation Nuclear Plant, INEEL/EXT-04-01816, June 30, 2004 


\section{Table of Contents (Cont'd)}

May 7, 2007

Section

Page

4.7 NGNP Technical Issues Safety Research Needs, 31 Stuart D. Rubin, presented June 7, 2006

4.8 Framework for Development of a Risk-Informed, 31 Performance-Based Alternative to 10 CFR Part 50, Working Draft, NUREG-1860, July 2006

5.0 How Regulatory Issues are Addressed by Current ASME Code Cases and Section III Subsection NH "Class 1 Components in Elevated Temperature Service."

5.1 Materials Creep Behavior, Creep Fatigue and 32 Environmental Effects

5.2 The Structural Integrity of Welds 33

5.3 Development and Verification Of Simplified Design 34 Analysis Methods

5.4 Verification Testing

6.0 Materials Models, Design Criteria and Analysis Methods Needed in the ASME Code to Cover Regulatory Issues for Very High Temperature Service

6.1 Materials Creep Behavior, Creep Fatigue and 35 Environmental Effects

6.2 The Structural Integrity of Welds 35

6.3 Development and Verification of Simplified Design Analysis 36 Methods

6.4 Verification Testing 36

$\begin{array}{lll}7.0 & \text { References } & 38\end{array}$

Appendix A 40

NRC Licensing Review of CRBR-1983

List of Elevated Temperature Structural Integrity Issues

Appendix B

May 2, 2007 NRC Draft for Review, "Further Analysis of Appendix A NRC Licensing Review of CRBR - 1983 List of Elevated Temperature Structural Integrity Issues." 


\section{Regulatory Safety Issues in the Structural Design Criteria of \\ ASME Section III Subsection NH for Very High \\ Temperatures for VHTR \& GEN IV \\ Report}

\subsection{EXECUTIVE SUMMARY}

The NRC and ACRS issues which were raised in conjunction with the licensing of the Clinch River Breeder Reactor (CRBR) provide the best early indication of regulatory licensing issues for high temperature reactors. A construction permit for CRBR was supported by the ACRS with the stipulation that numerous ACRS/NRC technical issues be resolved prior to requesting an operating license. The $R$ \& D program that was agreed upon to resolve elevated temperature structural integrity licensing issues was never implemented because Congress halted the construction of CRBR. The technical issues included materials, design analysis, weldment integrity, creep ratcheting, creep cracking and creep fatigue-creep rupture damage evaluations. The table in Appendix A lists twentyfive licensing concerns which the NRC asked the CRBR project to address. This 1983 list provides the most definitive description of NRC elevated temperature structural integrity licensing issues at that time.

Since the 1980s, the ASME Code has made numerous improvements in elevated-temperature structural integrity technology. These advances have been incorporated into Subsection NH of Section III of the Code. "Components in Elevated Temperature Service" [1]. The current need for designs for very high temperature and for Gen IV systems requires the extension of operating temperatures from about $1,400^{\circ} \mathrm{F}\left(760^{\circ} \mathrm{C}\right)$ to about $1742^{\circ} \mathrm{F}\left(950^{\circ} \mathrm{C}\right)$ where creep effects limit structural integrity, safe allowable operating conditions, and design life.

Materials that are more creep and corrosive resistant are needed for these higher operating temperatures. Material models are required for cyclic design analyses. Allowable strains, creep fatigue and creep rupture interaction evaluation methods are needed to provide assurance of structural integrity for such very high temperature applications. Current ASME Section III and NRC design criteria for lower operating temperature reactors are intended to prevent thru-wall cracking and leaking. 


\section{Regulatory Safety Issues in the Structural Design Criteria of ASME Section III Subsection NH for Very High \\ Temperatures for VHTR \& GEN IV}

Report

Section 4.0 of this report describes the NRC and ACRS work on elevated temperature structural integrity licensing issues subsequent to CRBR. Source documents for the NRC and NRC sponsored work are References 15 through 21, 23, and 24) in Section 7.0 herein. NRC has issued a number of definitive reports (see References 16,17,18,19 and 23 and 24). ORNL, ANL, and INEEL have performed the other studies and evaluations cited herein. A list of materials and design basis issues cited in a 1993 ORNL Report is given in Section 4.1 herein where the 10 most important issues are identified with an asterisk. Dr. Joseph Muscara of the NRC presented materials engineering needs for advanced high temperature reactor designs in coordination meetings with the ACRS in 2002. The major issues cited concerned the adequacy of Subsection $\mathrm{NH}$, and Code Cases $\mathrm{N}-201$ and $\mathrm{N}-499$. The safety issues cited are summarized in Section 4.3 herein, along with the relevant NRC research underway in 2002.

ANL provided two reports in 2003 describing a review and assessment of the materials behavior issues, and the Codes and Procedures for high-temperature gas cooled reactors (HTGRs). They state that Subsection $\mathrm{NH}$ is considered to be applicable to HTGR components that will operate at relatively low temperatures, and that the scope of Subsection $\mathrm{NH}$ needs to be expanded to include materials with higher allowable temperatures and other materials of interest. They cite Alloy 617, $9 \mathrm{Cr}-1 \mathrm{M} 0-\mathrm{V}$ steel and Hastelloy $\mathrm{X}$ as candidates for core support structures and vessel internals. Their major findings are given in Section 4.4 and 4.5 of this report.

DOE authorized INEEL to conduct a review of technology alternatives for the Next Generation Nuclear Plant (NGNP). Their report [Ref. 22 herein] was published June 30, 2004. While the results of their review, described in Section 4.6 herein, do not necessarily represent the licensing concerns of NRC, their recommendations are certainly relevant to structural design criteria and Code development. The NGNP is to be designed, constructed, licensed and operating by no later than 2020 , with a target date for initial operation of 2017 . INEEL believes that meeting these objectives will require technology stretch, and warns against attempting too great a stretch. Several nuclear system concepts for a VHTR for the NGNP were reviewed. These include the helium-cooled prismatic reactor, the helium-cooled pebble bed reactor and the molten salt-cooled prismatic reactor. Based on construction time objectives and material development requirements, INEEL recommended that maximum metal temperatures be limited to $900^{\circ} \mathrm{C}\left(1652^{\circ} \mathrm{F}\right)$. This corresponds to a maximum core average outlet temperature of $900-950^{\circ} \mathrm{C}\left(1652-1742^{\circ} \mathrm{F}\right)$. Even at $900^{\circ} \mathrm{F}$ $\left(1652^{\circ} \mathrm{F}\right)$ metal temperature, they state that some reactor core subassemblies might require replacement during the 60-year design plant life.

Stu Rubin of the NRC prepared a presentation on "NGNP Technical Issues Safety Research Needs" in June of 2006. His presentation, described in Section 


\section{Regulatory Safety Issues in the Structural Design Criteria of ASME Section III Subsection NH for Very High \\ Temperatures for VHTR \& GEN IV}

Report

4.7 herein, discusses the licensing framework, and related components, qualifications, fabrication and testing issues. The major metallic component technical issues he quotes as still requiring resolution include:

- Fatigue, creep and creep fatigue interaction;

- Coolant impurities and crevice concentration impacts;

- Metal carburization, decarburization and oxidation'

- Sensitization of austenitic steels;

- Alloy aging behavior at elevated temperatures;

- The adequacy of inservice inspection and;

- The applicability/adequacy of the ASME Code data base.

Section 4.9 herein summarizes the current NRC licensing issues for the structural design of VHTR and Gen IV systems. In order to resolve these issues, Subsection NH of Section III of the Code and the Code Cases for elevatedtemperature design require further development. The metal temperature limits of the Code need to be extended from $760^{\circ} \mathrm{C}\left(1400^{\circ} \mathrm{F}\right)$ to at least $900^{\circ} \mathrm{C}\left(1652^{\circ} \mathrm{F}\right)$. The design lifetime limit of 34 years needs to be extended to 60 years. Additional materials including Alloy 617 and Hastelloy $X$ need to be fully characterized. Environmental degradation effects, especially impure helium and those noted herein, need to be adequately considered. Since cyclic finite element creep analyses will be used to quantify creep rupture, creep fatigue, creep ratcheting and strain accumulations, creep behavior models and constitutive relations are needed for cyclic creep loading. Such strain- and timehardening models must account for the interaction between he time-independent and time-dependent material response.

The manner in which NRC licensing issues for the structural design of VHTR and Gen IV systems are addressed in the current ASME Subsection NH and Code Cases is described in Section 5.0 herein. The materials creep behavior, creep fatigue and environmental effects are addressed in Subsection NH and Code Cases largely in terms of design criteria and allowable stress and strain values.

The detailed material properties needed for cyclic finite element creep design analyses are generally not provided in the Code. The minimum strength properties given in the Code are used as anchor values for the more comprehensive material suppliers' average properties. The NRC perspective is that the Code and/or Code Cases currently do not adequately cover the material behavior under cyclic loads in the creep regime, and creep fatigue - creep rupture interaction effects.

Subsection $\mathrm{NH}$ has rules for the design of welded joints separated into categories $A$ through $D$. The permissible types of welded joints and their dimensional requirements are specified. Para. $\mathrm{NH}-3353$ provides analysis 


\section{Regulatory Safety Issues in the Structural Design Criteria of ASME Section III Subsection NH for Very High \\ Temperatures for VHTR \& GEN IV}

Report

requirements for the design and location of all pressure retaining welds operating at temperatures where creep effects are significant. Reduction factors for creep stress rupture are given as a function of time and temperature. Permissible weld metals are limited and special examination requirements are imposed.

Probably the most restrictive Subsection NH requirements for welds is that the inelastic accumulated strains are limited to one-half the allowable strain limits for the base metal. This has forced designers to keep welds out of high stress areas. The allowable fatigue at weldments is limited to one-half the design cycles allowed for the base metal. The allowable creep rupture damage at weldments is limited in $\mathrm{NH}$ by requiring that the rupture strength be reduced by the weld strength reduction factor when determining the time-to-rupture. The Code also imposes additional examination requirements on Category $A$ thru $D$ welded joints. The adequacy of these and other Code weldment structural design requirements has been questioned by the NRC, even for the temperatures currently covered, which are lower than the VHTR and Gen IV High Temperature Systems.

Section 6.0 herein describes the material models, design criteria and analyses methods which NRC has indicated are remaining needs in the ASME Code to cover Regulatory Issues for Very High Temperature Service. The Code technical committees involved are listed for each of these needs:

1. Material cyclic creep behavior, creep rupture/creep fatigue interaction and environmental effects.

2. The structural integrity of welds

3. The development of extended simplified design analysis methods (to avoid dependence on "black box" FEA for cyclic creep.)

4. Test verification of 1,2 and 3 .

The NRC is currently expanding its staff to deal with their increased licensing workload for Gen III reactors as well as to address Gen IV technical licensing issues. They have expressed concerns about the validity of extending the current technology of Subsection $\mathrm{NH}$ to much higher temperatures, and see the need to resolve new corrosion and structural integrity issues for the materials to be used for very high temperature applications. Appendix B gives the current (May 2, 2007) NRC Draft for Review, Further Analysis of Elevated Temperature Structural Integrity (Licensing) Issues. 


\subsection{INTRODUCTION}

The objective of this task is to identify issues relevant to ASME Section III, Subsection NH [1], and related Code Cases that must be resolved for licensing purposes for VHTGRs (Very High Temperature Gas Reactor concepts such as those of PBMR, Areva, and GA); and to identify the material models, design criteria, and analysis methods that need to be added to the ASME Code to cover the unresolved safety issues.

Subsection $\mathrm{NH}$ was originally developed to provide structural design criteria and limits for elevated-temperature design of Liquid Metal Fast Breeder Reactor (LMFBR) systems and some gas-cooled systems. The U.S. Nuclear Regulatory Commission (NRC) and its Advisory Committee for Reactor Safeguards (ACRS) reviewed the design limits and procedures in the process of reviewing the Clinch River Breeder Reactor (CRBR) for a construction permit in the late 1970s and early $1980 \mathrm{~s}$, and identified issues that needed resolution. In the years since then, the NRC and various contractors have evaluated the applicability of the ASME Code and Code Cases to high-temperature reactor designs such as the VHTGRs, and identified issues that need to be resolved to provide a regulatory basis for licensing.

This Report describes: (1) NRC and ACRS safety concerns raised during the licensing process of CRBR , (2) how some of these issues are addressed by the current Subsection NH of the ASME Code; and (3) the material models, design criteria, and analysis methods that need to be added to the ASME Code and Code Cases to cover unresolved regulatory issues for very high temperature service.

\subsection{NRC AND ACRS SAFETY ISSUES IN LICENSING REVIEW OF CRBR}

This section describes NRC staff and ACRS safety concerns with regard to the elevated-temperature structural design of LMFBR systems, related to licensing of the CRBR that took place during the late 1970s and early 1980s. The ACRS has statutory responsibilities as described in the Atomic Energy Act of 1954, as amended. The ACRS reviews and advises the Commission with regard to the licensing and operation of production and utilization facilities and related safety issues, the adequacy of proposed reactor safety standards, technical and policy issues related to the licensing of evolutionary and passive plant designs, and other matters referred to it by the Commission. 


\subsection{ELEVATED TEMPERATURE DESIGN AND OPERATING LICENSING CONDITIONS}

In order to assess the relevance of issues identified by the NRC and ACRS licensing reviews of CRBR to the structural design of VHTR and GEN IV systems, it is necessary to consider the specific design and operating conditions of the CRBR.

The Clinch River Breeder Reactor Plant was designed to demonstrate that a liquid metal fast breeder reactor can operate safely and reliably in an electric utility system. The plant was designed as a $350 \mathrm{MWe}$, three loop system to be located in the Tennessee Valley Authority system at a site on the Clinch River near Oak Ridge, Tennessee. With a reactor vessel outlet temperature of $995^{\circ} \mathrm{F}$ $\left(535^{\circ} \mathrm{C}\right)$ it was necessary in the structural design of the plant to take account of loading conditions and component response unique to elevated-temperature service - enhanced thermal transients and gradients, nonlinear deformation and creep of materials, and time-dependent failure modes. With a design life of 30 years it was necessary to take account of material degradation effects due to sustained load and environment, geometry change due to creep, and a potential for loss of function.

Since LMFBR systems operate at low pressure, the sodium containing components - reactor vessel, tanks, piping, heat exchangers, steam generators, pumps, and valves - are relatively thin-walled. Besides steady loads due to pressure, thermal expansion, and dead weight, there are cyclic loads due to thermal transients, pressure changes, and seismic events. Thermally induced stresses become more significant in elevated-temperature systems, so additional attention must be paid to elastic follow-up, strain concentration, and geometrical instability. In contrast with low-temperature design where the response is timeindependent, cyclic loads combine with elevated-temperature, time-dependent material behavior making it necessary to follow the actual load history through time and to predict response as a function of time. The ordering of events, as well as the time between events, may have a significant effect on response. 


\subsection{STRUCTURAL INTEGRITY EVALUATION APPROACH FOR LICENSING}

\subsection{Modes of Failure Considered}

Elevated-temperature CRBR systems and components were designed to meet the limits of the ASME Boiler and Pressure Vessel Code, Section III, Case N-47 (1981) [2], the forerunner of Subsection NH, which applies for ferritic steels at temperatures above $700^{\circ} \mathrm{F}\left(371^{\circ} \mathrm{C}\right)$ and for austenitic stainless steels above $800^{\circ} \mathrm{F}\left(427^{\circ} \mathrm{C}\right)$. Failure is prevented by: 1 ) identifying each possible failure mode, 2 ) determining the damage criterion for each failure mode, and 3) establishing design rules that appropriately separate design limits from initiation of failure. Other rules rely on control of geometry, design rules to specify details, and design factors based on experience to avoid failure, but do not treat each failure mode explicitly.

Case N-47 is based primarily on design by analysis since it is not possible to develop simple, generally applicable formulas to represent the time-dependent response of complex structures for a 30 year life. However, it did include a number of simplified limits and bounding methods. The latter were based on elastic and short-time plastic analyses which, although generally conservative, if satisfied, could avoid more detailed time-dependent, inelastic and creep analyses. The cost of analysis was a consideration. The modes of structural failure considered in CRBR design include:

- Ductile rupture from short-term loads.

- Creep rupture from long-term loads.

- Creep-fatigue failure.

- Gross distortion due to incremental collapse and ratcheting.

- Loss of function due to excessive deformation.

- Buckling due to short-term loads.

- Creep buckling due to long-term loads. 


\subsection{Stress Categories}

In Code Case $\mathrm{N}-47$, stresses and strains are categorized as primary $(P)$, secondary $(Q)$, or peak $(F)$, and in applying the limits, distinction is made between two types of quantities: 1) Load-Controlled, and 2) Deformation-Controlled. The load-controlled quantities result from equilibrium with applied loads during plant operation. Primary stress intensities are load-controlled quantities. Deformation-controlled quantities are stresses, strains, and deformations that result from deflection and/or strain compatibility. These quantities generally vary both with time and applied loads, and creep effects may be a major influence. Thus, accurate analytical evaluation of deformationcontrolled quantities generally requires inelastic stress analysis when creep effects are significant.

\subsection{Material Representation}

Modeling of time-dependent material behavior in multidimensional states of stress is fundamental to the accurate prediction of component response to service loads and to comparison with design limits.

For CRBR the material models (constitutive equations) were developed by the Oak Ridge National Laboratory and are described in RDT Standard F9-5T [3]. The constitutive relations [4] are based on observations largely from uniaxial test data for type 304 stainless steel and are applicable to 304 SS, 316 SS, and 21/4 Cr - 1 Mo steel. For time-independent, elastic-plastic calculations the von Mises yield criterion, its associated flow rule, and the linear kinematic hardening rule were used. For consistency, this requires use of an assumed bilinear uniaxial stress-strain relationship. Creep behavior is represented in the form of a creep law which includes both primary and secondary creep. This includes all the basic elements - elastic, plastic, primary and secondary creep strains - and the effects of plastic yielding and flow, cyclic plasticity, plastic strain hardening, creep strain hardening, and creep load reversal.

Small-strain theory was used since the Code strain limits essentially limit design strains to the range where small-strain theory is valid. The effects of prior plastic deformation on subsequent creep were neglected, and, except for hardening due to prior creep strains, the effects of prior creep deformation on subsequent elastic-plastic behavior were neglected. 


\subsection{STRUCTURAL INTEGRITY EVALUATION METHODS}

At the time CRBR was designed, the finite element method of structural analysis was already well established. Solutions for linear elastic problems could be obtained readily and accurately for relatively complex (3D) geometries and loading conditions. The solution of nonlinear, elastic-plastic-creep problems was less well established. It was impractical to do a full three dimensional inelastic analysis of a complete reactor system. However, neither was it necessary to do detailed analysis over extended regions of the system. Only part of the system operates at elevated-temperatures, and many components see elevated temperatures only for brief periods. Also, for the components that operate at elevated-temperatures, the magnitude of inelastic strain accumulation is critical only in very local regions, such as nozzles, elbows, flanges, connections, etc. So the general approach to design analysis was to determine interaction loads by equilibrium and compatibility considerations, and then analyze the highly stressed local regions in significant detail.

\subsection{Simplified Analysis Methods}

Simplification in structural analyses took the form of simplification of geometry, material model, loading conditions, or some combination thereof. For the solution of nonlinear, elastic-plastic-creep problems a number of special purpose computer programs were written to implement the ORNL material model for specific geometries such as one dimensional and plane (2D) thick cylinders and axisymmetric and 2-dimensional nozzles [5] and [6]. Programs were written using simplified material models to address specific failure modes such as creep ratcheting and creep buckling. The ORNL material model was also incorporated into the general purpose finite element programs, MARC and ANSYS, to address more complex geometries and loading conditions [7].

\subsection{Detailed Analysis of Localized Areas}

For CRBR, the design evaluation process proceeded from simple to complex. The design Code Case N-47 includes so-called screening rules that give limits for controlled quantities calculated elastically. The rules are very conservative in most cases but if they can be met, more detailed inelastic analysis is not required. A large part of the design was confirmed using the screening rules. If the screening rules cannot be met, then inelastic analysis is required. However, a 'simplified' inelastic analysis may suffice. It may be possible to show, using simplified representations of the structure, that stresses or strains are bounded and within design limits. If 'simplified' methods 
fail, a 'detailed' analysis is necessary. But the detailed analysis could generally be limited to very localized regions when proper account was taken of the gross behavior of the structure. It is not necessary, for example, to do an inelastic analysis of a complete pipeline when only the elbows are loaded inelastically [8].

\subsection{Models and Tests}

In order to validate the combination of material model, geometrical approximation, and computer implementation, a number of model and full scale tests were run and analyzed using simplified and detailed analyses [9]. Full scale tests were run on piping elbows, nozzle to cylinder attachments, and cylinders rotated between two opposing sodium jets [10]. The elbows were loaded to measure time-dependent plastic buckling, creep deformation, creep ratcheting, creep relaxation, and creep buckling. The nozzle (an FFTF IHX nozzle) was loaded to measure creep ratcheting and creep rupture. And the rotating cylinder was loaded to measure response to thermal striping. Tests on models included nozzles, cylinders, spheres, and plates (thermal striping). The test results were used to sharpen the analytical techniques and to gain expertise with their use on structural analysis of CRBR.

\subsection{REGULATORY SAFETY ISSUES}

\subsection{Perspective}

In the late 1960s the U. S. Department of Energy recognized that structural design methods used for light water reactor systems would not be adequate for the licensing of high-temperature liquid metal reactor systems. Although non-nuclear systems such as chemical process plants operate routinely at high temperatures, they do not have the demonstrated reliability required for long-term nuclear service with limited inspection. A program was thus initiated by the DOE and continued for about 15 years to develop the basis for hightemperature structural design and licensing of LMFBR systems.

A key feature of the program is that it was carried out simultaneously with design and construction of the Fast Flux Test Facility plant and with design of the CRBR plant. Project design needs were factored into the development program continuously, and results were used in ongoing design and evaluation. This process insured that the development programs were fully responsive to project design needs. 


\subsection{NRC Licensing Review}

Since design temperatures of LMFBR systems are significantly above those of the light water reactor systems more familiar to the NRC, close scrutiny was given to elevated-temperature effects as they relate to structural integrity and safety. The Nuclear Regulatory Commission identified a number of concerns in two major areas: 1) Code design limits, and 2) design evaluation procedures. Specific development programs were identified to be completed prior to issuance of a plant operating license. The review, which included input from U. S. national laboratories, manufacturers, and independent consultants, represented essentially an open forum assessment of the state-of-theart in elevated-temperature structural design evaluation. As a result of the extensive review, and with a plan agreed upon for resolution of the NRC concerns, NRC formally recommended issuance of a construction permit for CRBR.

In the Safety Evaluation Report, NUREG-0968 [11], related to construction of the CRBR, the Nuclear Regulatory Commission described the complicating effects of elevated-temperature service as follows:

"Systems and components in service at elevated temperatures are subjected to larger temperature variations and differentials than LWR hardware. Moreover, the materials have lower strength at elevated temperatures. The resulting higher thermal strain ranges and increased inelastic strain concentrations tend to accelerate fatigue damage. In addition, the materials are susceptible to creep-rupture damage that results from both applied and residual stresses persisting after transient conditions. Relaxation of such stresses tends to cause ratcheting on subsequent load cycles. The effective microscopic ductility of many of the materials and product forms is reduced by concentration of creep strains in grain boundaries. Consequently, cracking can occur at accumulated strain levels that would cause no problems at temperatures below the creep regime."

The NRC put together a 'laundry' list (1983) of areas where the effects of elevated-temperature might be significant and asked the CRBR Project to address those areas. To our knowledge this list was never published but it is included here as an Appendix A (taken from hand written notes) because of possible applicability to overview licensing of Very High Temperature and GEN IV systems. 
Based on a review of the material presented by the CRBR Project, the NRC (with ACRS) identified concerns in nine areas:

1. Weldment cracking

2. Notch weakening

3. Material property representation for inelastic analysis

4. Steam generator tubesheet evaluation

5. Elevated-temperature seismic effects

6. Elastic follow-up in piping

7. Creep-fatigue evaluation

8. Plastic strain concentration factors

9. Intermediate piping transition weld.

These concerns are described in detail in [12] and summarized briefly here:

\subsection{NRC Safety Concerns}

\section{Weldment Cracking}

Weldment cracking, particularly in components subjected to repeated thermal transient loads, was identified by NRC as the foremost structural integrity concern for CRBR. It is well-known that when structural failure occurs it is generally at weldments.

The design approach to weldment integrity was primarily to assure that weldments are at least as strong as the parent metal. Weldment configuration and processes were controlled, and the amount of delta ferrite which may transform to a brittle sigma phase was limited. In addition, reduced strain limits were specified which encouraged the placement of weldments in lower stressed regions. Case N-47 specified the use of parent metal properties to represent weldment behavior in life assessment procedures, so complex interaction between stress and strain at weldments was not taken into consideration. 


\section{Regulatory Safety Issues in the Structural Design Criteria of ASME Section III Subsection NH for Very High \\ Temperatures for VHTR \& GEN IV}

Report

The NRC assessment was that, because of the importance of weldment cracking as a failure mode, the designer should have a better understanding of the metallurgical interactions that take place in weldments and their effects on weldment life. Specifically, the NRC was concerned with: 1) early crack initiation at the inside wall surface in the heat-affected zone (HAZ) where the weldment is exposed to thermal cycling; 2 ) the effects of large variations of material properties within the weldment on creep-fatigue and creep-rupture damage; and 3 ) the effects of time rate, cycle rate, and hold time on the propagation of long shallow cracks in the HAZ of a weldment. They were also concerned about creep enhancement of crack growth in a cracked weldment, specifically, enhanced creep in the remaining uncracked wall caused by residual stress and thermal cycling, and effects of creep on stability of the remaining uncracked wall ligament. The NRC felt that as a minimum these effects must be considered and quantitatively evaluated in order to determine the safety margins of weldments in elevated-temperature components.

The basic concerns identified by NRC were:

- Evaluate potential for premature crack initiation at weldments due to thermal fatigue, residual stresses, and damage caused by the welding process.

- Confirm adequacy of creep-rupture and creep-fatigue damage evaluation procedures at weldments.

- Assess growth behavior of cracks in the heat affected zone of weldments.

- Evaluate consequences of enhanced creep in uncracked ligaments.

- Assess stability of uncracked ligaments for creep conditions.

- Define effects of long-term elevated-temperature service on crack initiation.

- Evaluate effects of loading sequence on creep-fatigue behavior.

It was required that these investigations be completed prior to issuance of a plant operating license. 


\section{Notch Weakening}

Cracking at notches and other local structural discontinuities in components was another area of major concern to the NRC. The situation is similar to that at weldments where material discontinuities lead to high local stresses. In the case of notches, the geometrical configurations lead to local stress concentrations and the potential for inelastic strain concentrations that may exhaust material ductility. Notches, small radius fillets, and localized structural discontinuities are regions observed in practice, besides weldments, where cracks tend to initiate.

The CRBR approach to avoid cracking was to avoid use of sharp geometrical discontinuities, and to place structural transitions in low stress regions. There were no special rules in Case N-47 that apply to notches. They were not considered in application of the LoadControlled limits but were considered in application of the Appendix T Deformation and Strain Limits (T-1300) and the Creep-Fatigue Limits (T-1400). Separate limits were provided for elastic and inelastic analysis. If the elastic limits could be met, then inelastic analysis was unnecessary. However, for CRBR, most regions with significant structural discontinuities had to be modeled inelastically. In fact, most of the inelastic analysis performed for the CRBR plant was to assure compliance with Case N-47 Appendix $\mathrm{T}$ rules at structural discontinuities.

The major concern of the NRC was that the design limits for fatigue and creep-rupture were based on tests of smooth-sided specimens that did not include possible effects of stress gradients in notches. They were also concerned about loss of ductility under long-term loads due to prior cyclic and monotonic straining. The NRC concerns are described as follows in the Safety Evaluation Report, NUREG0968 [11]:

"The basic allowable stress limits of the Code are based on unnotched creep specimen test data. Stress raisers influence the creep behavior of the entire wall in two basic ways. They introduce a constraint against inelastic flow by inhibiting slip line development. This is manifested in a reduction in the average stress intensity in the net section (a notch strengthening effect). Stress raisers also introduce a site where creep-rupture damage could cause early crack initiation and more rapid crack propagation (a notch weakening effect). Although the combined effect is notch strengthening in most cases, 
an evaluation is needed to determine what geometric, loading, and material parameters could cause significant notch weakening, particularly for long-term loads at elevated temperatures. Loading conditions such as transverse shear do not introduce any notch strengthening and have contributed to weldment cracking at structural discontinuities."

A confirmatory program was developed jointly between the NRC and the CRBR Project to address these concerns. The basic elements of the program are summarized as follows:

- Extend the elastic constraint damage evaluation method to include cyclic and bending loads.

- Implement effects of material ductility in the damage evaluation procedure.

- Apply the extended method to "worst case" geometric notches in CRBR components.

- Compare effects of tensile stress vs. stress intensity on creeprupture.

- Develop cyclic creep strain concentration factors for notches in creep-fatigue and perform trial applications.

It was required that these investigations be completed prior to issuance of a plant operating license.

3. Material Property Representation for Inelastic Analysis

The NRC reviewed analysis methods and applicable design criteria used for CRBR design. Concerns were expressed on the impact of new technology developments on safety, the verification of computer programs for use in inelastic analysis, and use of alternative strain limits in NE Standard F9-5T. These were resolved by Project commitments to assess the potential CRBR safety implications of new developments, provide verification and qualification of computer programs used in design, and to not use strain limits based on elastic analysis in final design justification.

An NRC issue that required a confirmatory program to be completed prior to application for an operating license concerned the suitability of using material average properties for inelastic analysis. 
The CRBR Project approach to inelastic analysis followed the guidance provided by NE Standard F9-4T, which states:

"When inelastic analysis is used in preparation for a creepfatigue or inelastic strain evaluation, the plasticity and thermal creep properties used in the analysis shall be average (or conservative). It is intended that the results of analysis based on "average" properties be compared to the Code supplied stress-rupture and fatigue limits."

This applies to the strain and creep-fatigue limits of Case $\mathrm{N}-47$, but not to the buckling limits where the use of minimum strength properties is required. The rationale, which was established and affirmed by a strong national consensus, was that it is impractical to determine the worst case combination of minimum and/or maximum strength and deformation properties for each load combination. Nor would it be representative of actual material behavior because worst case combinations are not physically consistent. It was considered that material variations from the "average" are covered by Code design margins.

The NRC concern was that creep-rupture damage calculated using average properties may be too low when compared with the considerable strain and cyclic hardening that occurs during fabrication and operation, and that the fatigue damage and accumulated strains may be too low if the actual yield strength is below the average value used in design analysis.

The confirmatory program identified to resolve these concerns required an evaluation of the significance of material property variations where inelastic analysis is used to evaluate elevatedtemperature components containing radioactive sodium. The following requirements were imposed:

- Minimum yield strength and minimum creep deformation strength $(80 \%$ of the average isochronous plots) properties shall be used to evaluate fatigue damage, as represented by the use fraction, and the accumulated inelastic strains.

- The fatigue damage fraction and the creep-rupture damage, represented by the time fraction, are to be reported to the NRC for both minimum and average material properties using the method of Case $\mathrm{N}-47$. 
- The creep portions of the total accumulated inelastic strains (membrane, bending, and peak) are to be reported using the method of Case $\mathrm{N}-47$.

- Structural adequacy of the components shall be demonstrated using these calculated values of damage and inelastic strain.

- Minimum and average properties shall be considered in performing the other confirmatory programs on Weldment Safety Evaluation, Notch Weakening, and the Steam Generator.

\section{Steam Generator Tubesheet Evaluation}

The Nuclear Regulatory Commission review of the CRBR steam generator design procedures was conducted prior to Project completion of design evaluation. The planned evaluation included mechanical property, feature, and prototypic tests to verify and supplement analysis methods and Code design procedures. As part of the confirmatory program the Project committed to completion of the planned test program including an hydraulic test model, large leak tests, tube tests, departure from nuclear boiling tests, tube support wear tests, modular steam generator tests, single-tube performance tests, stability and interaction tests, tube-to-tubesheet weld tests, scaled hydraulic model feature tests, and flow induced vibration tests.

The major NRC concern relative to the Steam Generator was assurance of adequacy of the tubesheet for the design life of the component. Specifically, the concern was adequate calculation of the highly localized, inelastic stress in the outer row of ligaments due to radial thermal gradients and bulk temperature difference between the perforated and unperforated regions. Section III of the ASME Code provides a simplified method of analysis based on the equivalent solid plate concept. However, this method was not applicable for the CRBR Steam Generator tubesheet where the loading is dominated by large thermal gradients, and deformations are inelastic. The CRBR Project plan was to use detailed inelastic finite element analysis of sectors of the tubesheet in conjunction with the strain and creep-fatigue limits for inelastic analysis in Case N-47 for elevated-temperature design.

The NRC had concerns with this approach because of difficulties in modeling ligaments and the complex thermal-structural interaction with the rim and the tubes. Their approach essentially was to extend the Section III design procedure based on the equivalent solid plate concept to include the effects of thermal gradients, plasticity, and creep. 
The specific confirmatory program, that the Project agreed to carry out, was stated as follows:

- Develop effective properties of the perforated region for use in design inelastic analysis.

- Evaluate the effects of thermal gradients and equivalent material property variations on ligaments near the periphery of the perforated region.

- Extend existing Appendix A-8000 Code methods for calculating the linearized membrane, shear, and in-plane bending stresses in the ligaments using the equivalent solid plate stresses. Include all of these nominal stresses in the comparison with allowable primary membrane plus bending, and primary plus secondary allowables.

- Develop methods of evaluating local cyclic plastic and creep strain concentration effects based on equivalent solid plate stresses for use in the fatigue evaluation.

- Evaluate elastic follow-up in the outermost ligaments: 1) reclassify the portion of the discontinuity stresses caused by pressure and mechanical loads as "primary" in accordance with the associated amount of elastic follow-up that occurs during thermal transients, and 2) reclassify the portion of thermal stresses as "primary" in accordance with the amount of elastic follow-up that occurs during thermal transients.

- Develop ratcheting evaluation methods for the outermost ligaments based on elastic equivalent solid plate stresses reclassified as above and including nominal membrane, shear, and in-plane bending stresses.

- Develop creep rupture damage evaluation methods for the outermost ligaments based on equivalent solid plate stresses. The effects of elastic follow-up will reduce the amount of stress relaxation and increase the creep-rupture damage.

- Perform detailed tube-to-tubesheet joint analysis for tubes in the high radial thermal gradient region at the periphery of the perforated region and include local thermal effects.

This extensive program was to be completed prior to issuance of a plant operating license.

\section{Elevated-Temperature Seismic Effects}

This issue concerns the possible enhancement of creep strain accumulation and creep-rupture damage resulting from seismic events. 
Case N-47 imposes limits on accumulated inelastic strain and creepfatigue damage but does not provide guidance on cyclic load history modeling of combined events. Seismic events impose short-term primary stresses on structures that affect the inelastic strain accumulation by changing residual stress distributions. Seismic loads may also produce plastic strain accumulation by ratcheting if the event is sufficiently severe. Relaxation of the increased residual stresses that exist after a seismic event may produce enhanced creep during subsequent service at elevated temperatures. Consequently, the sequence of loading becomes important in the creep regime.

This issue was resolved by a Project commitment to take into account any enhanced creep (ratcheting) and any creep-rupture damage resulting from residual stresses at local stress raisers following seismic events. This was accomplished practically using an approximate procedure to simulate dynamic seismic loading as an equivalent static load for inelastic analysis. The procedure, developed under the LMFBR Program and reported in ASME Paper 82-PVP-28 [13], utilizes the results of a linear seismic response spectrum analysis to calculate external loads. These statically equivalent loads are selected such that they produce internal forces and moments comparable to those predicted by the linear response spectrum analysis. The equivalent static load for the seismic event is applied after the first system heat-up when it is most damaging because the stresses have not yet relaxed during creep hold time. This procedure accounts conservatively for enhancement of accumulated strain and creep-rupture damage due to seismic loads.

\section{Elastic Follow-Up in Piping}

This issue concerns Project categorization of thermal expansion stresses as secondary for evaluation of hot leg piping. During creep relaxation a portion of the elastic strain is converted to creep strain. Areas of piping that are more highly stressed are subjected to additional cyclic strain and strain accumulation resulting from elastic follow-up. To provide adequate safety margins, Case N-47 requires that secondary stresses with a large amount of elastic follow-up be treated as load-controlled quantities. However, Case N-47 does not provide criteria that determine when elastic follow-up is considered large. 


\section{Regulatory Safety Issues in the Structural Design Criteria of ASME Section III Subsection NH for Very High \\ Temperatures for VHTR \& GEN IV}

Report

The issue was resolved by agreement between the NRC and the Project on a method for quantifying elastic follow-up and a criterion for determining the portion of thermal expansion stress to be treated as primary. A simplified elastic analysis procedure to estimate the amount of elastic follow-up due to thermal expansion stress in a thinwalled piping system was developed under the LMFBR Program and reported in ASME PVP-Vol. 86 [14]. The reduced elastic modulus concept was used to represent creep, and elastic follow-up was quantified relative to the Case $\mathrm{N}-47$ primary stress limit. The simplified method was validated by comparison with results of detailed inelastic analysis. Application of the agreed-upon method to the CRBR hot leg piping confirmed that elastic follow-up is negligible and that thermal expansion stresses are appropriately categorized as secondary for the hot leg design conditions.

\section{Creep-Fatigue Evaluation}

The Nuclear Regulatory Commission identified three concerns relative to creep-fatigue evaluation. The first was a Project modification of the creep-fatigue damage rule of Case N-47 when applied to austenitic stainless steel types 304 and 316 for components not to be Code stamped. The Code required that creep damage during compressive hold periods be taken equal to the creep damage during tensile hold periods for stresses of equal magnitude. The Project modification took creep damage in compressive hold to be $20 \%$ of that in tensile hold. This was accepted by NRC upon proper documentation of the experimentally based justification.

The second NRC concern was the treatment of high cycle fatigue due to thermal fluctuations and flow-induced vibrations that require evaluation beyond the Case $\mathrm{N}-47$ design curve limit of $10^{6}$ cycles for stainless steels. The Project extrapolated the fatigue curve beyond $10^{6}$ cycles using a slope of -0.12 on cycles for load-controlled situations, and developed a special purpose high cycle fatigue criterion for strain-controlled situations. The concern was resolved by demonstration that the Project extrapolation is more conservative at $800^{\circ} \mathrm{F}\left(427^{\circ} \mathrm{C}\right)$ than the high cycle fatigue design curve up to $10^{11}$ cycles adopted by the Code in 1982, and by implication from additional elevated-temperature data. The Project also provided data to support the special limit used for strain-controlled situations.

The third concern was fatigue design limits for $2 \frac{1}{4} \mathrm{Cr}-1$ Mo steel, which was resolved by a Project commitment to meet the elevatedtemperature fatigue design limits that had been recently approved by 
ASME Code Committees.

\section{Plastic Strain Concentration Factors}

For simplified elastic-plastic analysis, Section III of the Code allows the plastic strain concentration factor, $\mathrm{K}_{\mathrm{e}}$, to be taken as unity until the range of primary plus secondary stress intensity exceeds $3 S_{m}$. The NRC concern was that this factor actually begins to exceed unity when the local maximum stress range, including the elastic stress concentration factor, exceeds $2 S_{y}$. Also, strain multipliers for the concentration of plastic strain on the weaker side of a product form or materials interface are not included in formulas for $\mathrm{K}_{\mathrm{e}}$ in the Code.

This concern was resolved by a Project commitment to determine the actual plastic strain concentration, or to use a conservative approximation of concentration effects and the resulting fatigue design life when the local maximum stress range exceeds $2 \mathrm{~S}_{\mathrm{y}}$.

\section{Intermediate Piping Transition Weld}

The intermediate heat transport system transition weld reference design was a trimetalic joint consisting of type $316 \mathrm{H}$ stainless steel, Alloy $800 \mathrm{H}$, and $2 \frac{1}{4} \mathrm{Cr}-1$ Mo steel. Due to its complexity, the transition weld was evaluated in detail using the procedures of Case $\mathrm{N}-47$ and applicable DOE Standards. The effects of creep, residual stress, and differences in properties between the component materials were modeled using inelastic analysis.

Although demonstration of design life had not been completed, the NRC was concerned about the minimum expected carbon content of $0.05 \%$ at $936^{\circ} \mathrm{F}\left(502^{\circ} \mathrm{C}\right)$, the importance of variation in properties between the different materials, and the possible increase in creeprupture damage resulting from the higher yield strength properties produced by hardening in a multipass welding process.

Resolution of the NRC concern was achieved by Project commitment to perform analysis using the methods and criteria to be developed under the confirmatory programs to address issues relating to Weldment Cracking and Material Property Representation for Inelastic Analysis. 


\subsection{SUMMARY of CRBR Licensing Review}

Licensing review of the CRBR plant served essentially as an open forum assessment of elevated-temperature structural integrity design technology. The basic design approach was to treat areas of uncertainty either by design configuration or very conservative design margins. The major NRC concerns involved treatment of discontinuities - weldments, notches, and tubesheets - and areas where the ASME Code treatment was lacking. Resolution required Project commitment to develop more detailed evaluation techniques. As a result of the review NRC formally recommended issuance of a construction permit to CRBR.

\subsection{CURRENT NRC SAFETY ISSUES FOR STRUCTURAL DESIGN OF VHTR AND GEN IV SYSTEMS}

Since the NRC licensing review of the Clinch River Breeder Reactor during the late 1970's and early 1980's, NRC has continued to identify and investigate safety issues relative to structural design of High Temperature Advanced Reactor Systems.

\subsection{MATERIALS AND DESIGN BASES IN ASME CODE CASE N-47, NUREG/CR-5955, April 1993}

In anticipation of next-generation advanced power reactors for utilities, NRC sponsored an evaluation of the design bases (principally ASME Code Case N47) for the design and operation of reactors at elevated temperatures where the time-dependent effects of creep are significant and must be considered in the design process [15]. The reactor systems contemplated include advanced liquidmetal reactors, gas-cooled reactors, and possibly the Canadian CANDU reactors. The evaluation is not design specific, nor does it address specific reactor components such as transition joints, tube sheets, and bellows. Its main objective is to identify and summarize the issues that must be resolved in order to avoid the creep-induced failure modes of creep-rupture, creep-fatigue, creepratcheting, and creep-buckling.

A total of 23 issues were identified and described. They are characterized and classified by 1)Type - safety or economical; 2)Bases - material and data base, design bases, or both; and 3) Level - used to further delineate the issues into six categories based on a number of factors depending on considerations of plant safety, plant economics, expected cost to resolve the issue, expected calendar time required to resolve the issue, whether Code rules must be extended if they are to be used as the design bases for future 60-year high-temperature plants, etc.. All but two of the issues were safety related. The 23 issues are listed here, and the 10 considered most important are identified by an asterisk: 
1. Lack of material property allowable design data/curves for 60 -year design life.*

2. Degradation of material properties at high temperatures due to long-term irradiation. *

3. Degradation of material properties due to long-term thermal aging.

4. Degradation of material properties due to corrosion phenomena. ${ }^{*}$

5. Lack of property allowables based on current melting and fabrication practices.

6. Degradation effect of small cyclic stresses.

7. Creep-induced failures at temperatures below Code Case N-47 limits.

8. Use of average vs minimum material properties in design.

9. Lack of a design methodology for Modified $9 \mathrm{Cr}-1$ Mo steel

10. Lack of understanding/validation of effects of short-term overload events on subsequent material properties.

11. Lack of validated thermal striping materials and design methodology.*

12. Lack of reliable creep-fatigue design rules. ${ }^{*}$

13. Difficult, overly conservative ratcheting design rules.

14. Lack of a validated weldment design methodology. *

15. Lack of flaw assessment procedures. *

16. Uncertainty of multiaxial stress state effects.

17. Uncertainty of non radial (non proportional) loading effect.

18. Lack of understanding/validation of notch weakening effects. ${ }^{*}$

19. Lack of conservatism in Code rules for simplified fatigue evaluation based on plastic strain concentration factors.

20. Lack of validated rules/guidelines to account for seismic effects at elevatedtemperatures. ${ }^{*}$

21. Lack of inelastic design procedures for piping. *

22. Overly conservative buckling rules.

23. Need for thermal stratification design guidelines.

All issues except numbers 9 . and 13 . are considered to be safety related. The issues were described and elaborated but detailed plans for their resolution were not offered.

\subsection{SAFETY EVALUATION OF THE POWER REACTOR INNOVATIVE SMALL MODULE (PRISM) LIQUID-METAL REACTOR}

The PRISM reactor design proposed by DOE is for a small, modular, pool-type, liquid-metal (sodium)-cooled reactor producing $471 \mathrm{MWt}$ power. The standard plant design consists of three PRISM modules with a total electrical output rating of $1395 \mathrm{MWe}$. The primary and intermediate sodium outlet temperatures are $905^{\circ} \mathrm{F}\left(485^{\circ} \mathrm{C}\right)$ and $830^{\circ} \mathrm{F}\left(443^{\circ} \mathrm{C}\right)$ respectively, but under certain transient conditions the reactor vessel wall may reach the core outlet temperatures which increase to between $1100^{\circ} \mathrm{F}\left(593^{\circ} \mathrm{C}\right)$ and $1300^{\circ} \mathrm{F}\left(704^{\circ} \mathrm{C}\right)$. Thus, the design 


\section{Regulatory Safety Issues in the Structural Design Criteria of ASME Section III Subsection NH for Very High \\ Temperatures for VHTR \& GEN IV}

Report

temperatures are not significantly greater than for CRBR. However, the design life is for 60 years compared to 30 years for CRBR, which introduces some additional material degradation issues.

The NRC staff performed a preapplication safety evaluation of PRISM and published their findings in NUREG-1368 [16] dated February 1994. The objective was to provide at least the level of safety that is required for currentgeneration LWRs. The Preapplication Safety Evaluation Report did not result in design approval, but identified key safety issues and assessed the adequacy of the applicant's research and development programs. The overall conclusion was that there are no major impediments to licensing of the design.

Safety issues identified by NRC requiring resolution concerned primarily inelastic and limit analysis, Code Case N-47 (forerunner of Subsection $\mathrm{NH}$ ) and other elevated-temperature Code Cases, load combinations, and environmental effects associated with extrapolation of Case N-47 applicability from 34 years to 60 years.

It was pointed out that the NRC staff has not endorsed Code Case N-47 and, in general, has not accepted the application of inelastic stress and deformation limits in the initial design evaluations. Further review and justification are needed for the definition of load combinations, the application of inelastic and limit analysis in conjunction with the dynamic analysis, and the consideration of all types of time-dependent failure modes detailed in Case N-47.

Environmental effect issues include stress corrosion, flowing sodium effects, and neutron embrittlement. Stress corrosion is an issue because Type 316, used for the reactor vessel, is an austenitic sensitized stainless steel and subject to stress corrosion cracking at the higher temperatures associated with certain transients. An area of particular concern is the weld between the core support structure and the reactor vessel. In a dynamic sodium environment the concern is that the vessel can experience two types of degradation: erosion-corrosion and property changes. Erosion-corrosion decreases the effective load-carrying thickness, and property changes can decrease time-independent and time-dependent strength properties. Neutron embrittlement is a concern because the reactor vessel is designed for a 60-year lifetime and exposed to neutron irradiation which decreases ductility and fracture resistance.

In order to meet a design life of 60 years the elevated-temperature Code Cases $\mathrm{N}-47, \mathrm{~N}-201$, and perhaps $\mathrm{N}-48, \mathrm{~N}-49, \mathrm{~N}-50$, and $\mathrm{N}-51$, will have to be extrapolated from the present 34 year lifetime. 


\subsection{MATERIALS ENGINEERING RESEARCH NEEDS FOR ADVANCED REACTORS - ACRS, USNRC/RES, AND ORNL}

Several presentations were made by Dr. Joseph Muscara of NRC in 2002 at coordination meetings with ACRS, USNRC/RES, and ORNL to review materials engineering needs for advanced (high-temperature) reactor design [17-19]. The major issues concern the applicability of structural design codes - Section III, Subsection NH and Code Cases N-201 and N-499 - to high temperature applications. These codes are based primarily on studies and data gathered in the 1970s and 1980s for design of LMFBRs with maximum temperatures in the range of $1100^{\circ} \mathrm{F}\left(593^{\circ} \mathrm{C}\right)$ to $1500^{\circ} \mathrm{F}\left(816^{\circ} \mathrm{C}\right)$. There is a need to extend these codes, particularly in the areas of creep, creep-fatigue, and environmental effects, to cover higher temperatures and include data bases developed in recent years.

Safety issues identified for high temperature (unspecified) structural design of metallic components include:

- Lack of appropriate data bases for calculating fatigue, creep, creepfatigue, and stress corrosion cracking (SCC) lifetimes, including environmental effects

- Effects of impurities including oxygen on degradation

- Aging behavior of alloys

- Sensitization of austenitic alloys and weldments

- Degradation by carburization, decarburization, and oxidation

- Treatment of connecting pipe as a vessel for code application

NRC research underway in 2002 included:

- Review and evaluation of current national and international engineering design codes for components in HTGRs, including codes and methodology developed in Germany, Japan, China, United Kingdom, and France

- Review of existing literature and studies on HTGR materials and environmental effects on various degradation mechanisms

- Development of NUREG/CR-6824, Materials Behavior in HTGR Environments. 


\subsection{REVIEW AND ASSESSMENT OF CODES AND PROCEDURES FOR HTGR COMPONENTS, NUREG/CR-6816 JUNE 2003 [20]}

The objective of this task was to review and evaluate currently available national and international codes and procedures to be used in design of high-temperature gas-cooled reactors (HTGRs) including, but not limited to, the Pebble Bed Modular Reactor (PBR) and the Gas Turbine-Modular Helium Reactor (GT-MHR) designs. The evaluation is based on the materials that have been used or recommended for HTGRs, taking into account the HTGR operating environments. The ASME B\&PV Code components reviewed include Section III, Subsections NB and NH, Code Cases N-499-1 and N-201-4, and a Draft Code Case for Alloy 617 for very-high temperature design.

The major findings of the evaluation are that:

- Most of the materials needed for HTGR are not included in the code cases. New code cases will be needed.

- The maximum temperature permitted by the codes and code cases for materials acceptable for HTGR components is lower $\left(760^{\circ} \mathrm{C} / 1400^{\circ} \mathrm{F}\right)$ than the maximum temperature $\left(\geq 850^{\circ} \mathrm{C} / 1562^{\circ} \mathrm{F}\right)$ that these components may experience during operation. The Code needs to be expanded to include materials and limits for $850^{\circ} \mathrm{C}\left(1562^{\circ} \mathrm{F}\right)$ and higher.

- The codes and code cases do not provide specific guidelines for environmental effects, especially the effect of impure helium on the hightemperature behavior (e.g., fatigue, creep, and creep-fatigue) of the materials considered. High-temperature fatigue life may be influenced more by environment than by creep damage for some materials.

Subsection NB is considered to be applicable to those HTGR components (e.g., pressure vessel) that will operate at relatively low temperatures.

Subsection NH provides design rules for construction of out-of-core nuclear structures fabricated from only five materials. This is potentially the biggest obstacle to its use in the design of HTGR components. The scope of Subsection $\mathrm{NH}$ needs to be expanded to include materials with higher allowable temperatures and other materials of interest. The candidate materials for core support structure and vessel internals include Alloy 617, 9Cr-1Mo-V steel, and Hastelloy X.

There are other concerns with the use of Subsection NH for design of HTGR components. Its rules are written for materials that follow a classical creep curve consisting of primary, secondary, and tertiary creep. However, many of the materials being considered (e.g., Alloy 617) do not show any evidence of primary or secondary creep. New rules are needed for such materials. Subsection $\mathrm{NH}$ 


\section{Regulatory Safety Issues in the Structural Design Criteria of ASME Section III Subsection NH for Very High \\ Temperatures for VHTR \& GEN IV}

Report

does not require inelastic stress analysis to be conducted with rate-dependent, high-temperature unified constitutive equations (no distinction between creep and plastic strain), which are necessary when components operate at temperatures above $1200^{\circ} \mathrm{F}\left(649^{\circ} \mathrm{C}\right)$. At the higher temperatures, the tensile stress-strain relations depend on strain rate, and the classical distinction between plasticity and creep becomes untenable. Thus, strain rate effects need to be included in Code design analyses for very high temperatures. Subsection NH states that the combined effects of exposure to elevated temperature, contacting fluid, and nuclear radiation on material properties shall be considered. However, the Code does not provide specific guidelines for considering environmental effects. The conclusion is that more mechanistically based predictive methods are needed to handle the various material-specific damage mechanisms in different environments.

The scope of Code Case N-499-1 should be expanded to include $9 \mathrm{Cr}-1 \mathrm{Mo}-\mathrm{V}$ steel, which is specified for an uninsulated reactor vessel with an operating temperature of about $500^{\circ} \mathrm{C}\left(932^{\circ} \mathrm{F}\right)$. The effects of helium environment, including impurities, on the elevated-temperature $\left(500^{\circ} \mathrm{C} / 932^{\circ} \mathrm{F}\right)$ fatigue design curve, isochronous stress-strain curves, stress rupture curves, and the creepfatigue damage envelope need to be evaluated to further assess the applicability of this code case to low-alloy steel pressure vessel materials.

Code Case N-201-4 provides design rules for construction of core support structures fabricated from the same five materials covered in Subsection $\mathrm{NH}$. The maximum temperature permitted by this case for the materials acceptable for use in $\mathrm{HTGR}$ is $760^{\circ} \mathrm{C}\left(1400^{\circ} \mathrm{F}\right)$. Since the GT-MHR core support structures may experience temperatures of $850^{\circ} \mathrm{C}\left(1562^{\circ} \mathrm{F}\right)$ or higher, the scope of the code case needs to be expanded to include materials with higher allowable temperatures. The candidate materials for core support structures and vessel internals are Alloy 617 and $9 \mathrm{Cr}-1 \mathrm{Mo}-\mathrm{V}$ steel. As with Subsection $\mathrm{NH}$ the deleterious effects of primary coolant and nuclear radiation need to be considered.

The Draft Code Case for Alloy 617 was patterned after relevant portions of Subsection $\mathrm{NH}$, and limited to Alloy 617 , a temperature of $1800^{\circ} \mathrm{F}\left(982^{\circ} \mathrm{C}\right)$, and a maximum service life at temperatures above $800^{\circ} \mathrm{F}\left(427^{\circ} \mathrm{C}\right)$ of 100,000 hours. Most of the design rules addressed by the draft code case are similar to those provided by $\mathrm{NH}$. Some design rules are different because the code case considers higher temperature and a different material. At the very high temperatures of interest, Alloy 617 exhibits unique material behavior which includes (1) lack of clear distinction between time-independent and timedependent behavior, (2) high dependence of flow stress on strain rate, and (3) softening with time, temperature, and strain. One result is that the case specifies that inelastic analysis for temperatures above $1200^{\circ} \mathrm{F}\left(649^{\circ} \mathrm{C}\right)$ must be based on 


\section{Regulatory Safety Issues in the Structural Design Criteria of \\ ASME Section III Subsection NH for Very High \\ Temperatures for VHTR \& GEN IV}

Report

unified constitutive equations which do not distinguish between time-independent plasticity and time-dependent creep.

The Draft Code Case for Alloy 617 is a work in progress and its completion requires further development of the code case, material data base, and structural design methodology. In the code area, Alloy 617 must be added to the lowtemperature rules of Section III; and weldment stress rupture factors, thermal expansion coefficients, and isochronous stress-strain curves for the temperature range $427^{\circ} \mathrm{C}\left(800^{\circ} \mathrm{F}\right)$ to $649^{\circ} \mathrm{C}\left(1200^{\circ} \mathrm{F}\right)$ must be added to the Code Case. In the materials area, weldment fatigue data and a more complete creep-fatigue database are needed. Also, the synergistic effects of aging, environment, loading, and temperature need to be better understood, and the effects of aging on toughness must be characterized. Relative to structural design methodology, the unified constitutive model needs to be further developed, simplified ratcheting evaluation procedures are needed at temperatures above $649^{\circ} \mathrm{C}\left(1200^{\circ} \mathrm{F}\right)$, and very high-temperature structural model tests are needed to validate the design methodology. Probably the greatest need is to develop a more suitable damage theory to replace use of the linear damage fractions as the basis for the creepfatigue rules.

\subsection{MATERIALS BEHAVIOR IN HTGR ENVIRONMENTS, NUREG/CR- 6824 July 2003 [21]}

The objective of this task was to review and evaluate available information on performance and long-term behavior of materials in environments that are typical of high-temperature helium-cooled reactors. The availability and adequacy of design codes, rules, and procedures for component structural design are discussed in the companion report, NUREG/CR-6816 [20], described previously. However, the results presented here are pertinent because they provide the current state of knowledge on candidate structural materials that must be treated in the Code for nuclear structural design.

The primary helium coolant in the gas turbine-based HTGRs is expected to be at temperatures in the range of $850-900^{\circ} \mathrm{C}\left(1562-1652^{\circ} \mathrm{F}\right)$, and the selected materials should have adequate performance over the long service life at temperatures in the range of $900-950^{\circ} \mathrm{C}\left(1652-1742^{\circ} \mathrm{F}\right)$. Among the materials, $2 \frac{1}{4} \mathrm{Cr}-1 \mathrm{Mo}$ and modified $9 \mathrm{Cr}-1 \mathrm{Mo}$ ferritic steels are considered for application in reactor pressure vessels. Fe-Cr-Ni alloys such as Alloy $800 \mathrm{H}$ and austenitic stainless steels are considered for recuperators and reactor internals. Alloy 617, Hastelloy $X$, and Hastelloy $X R$ are considered for components that will be exposed to helium coolant at temperatures up to $900^{\circ} \mathrm{C}\left(1652^{\circ} \mathrm{F}\right)$. The key technical issues addressed were:

- Baseline mechanical property data 
- Effects of helium coolant chemistry on materials degradation

- Corrosion effects on mechanical properties of candidate materials

- Fission product release and its effect on materials

- Corrosion-erosion due to particulate-laden gas flow.

The major findings of this task concern environmental effects on material properties. Some pertinent conclusions are:

- The primary materials for high-temperature application in HTGRs that have been studied in detail are Alloys $800 \mathrm{H}$ and 617 and Hastelloy X. Among them, Alloy $800 \mathrm{H}$ is code certified for temperatures up to $760^{\circ} \mathrm{C}$ $\left(1400^{\circ} \mathrm{F}\right)$ for use in nuclear systems. A substantial database has been developed for both Alloys $800 \mathrm{H}$ and 617 , and a limited database exists for Hastelloy X.

- Even though helium by itself is inert towards the materials, it is often contaminated by small amounts of gaseous impurities. The gas chemistry and the thermodynamic activity for carbon and oxygen in the gas phase are difficult to ascertain because of the nonequilibrium nature of the gas mixture. Also, most studies on gas chemistry simulations were performed close to atmospheric pressure, whereas the system pressure in the reactor is on the order of $7 \mathrm{MPa}$.

- Structural alloys can be significantly corroded by the gaseous impurities in helium at elevated temperatures. Corrosion of heat resistant materials such as austenitic stainless steels, Alloy $800 \mathrm{H}$, and Alloy 617 may involve oxidation, carburization, and decarburization. Furthermore the corrosion process is "dynamic" in that it is dictated by the exposure time, gas chemistry variations, integrity of the corrosion product scales, and pressure of particulates in the gas phase.

\subsection{DESIGN FEATURES AND TECHNOLOGY UNCERTAINTIES FOR THE NEXT GENERATION NUCLEAR PLANT, INEEL/EXT-04-01816, JUNE 30, 2004 [22]}

The United States Department of Energy (DOE) authorized the Idaho National Engineering and Environmental Laboratory (INEEL) to have the Independent Technology Group (ITRG) conduct a review of technology alternatives for meeting the functional objectives for the Next Generation Nuclear Plant (NGNP). The results of the review do not necessarily represent the concerns of NRC, however, the ITRG is a broadly experienced group and has offered conclusions, observations, and recommendations that are relevant to structural design code development. 


\section{Regulatory Safety Issues in the Structural Design Criteria of \\ ASME Section III Subsection NH for Very High \\ Temperatures for VHTR \& GEN IV \\ Report}

The high-level functional objectives of NGNP include demonstrating an economically viable nuclear system, licensable in the United States, with commercially attractive production capabilities including high-efficiency power conversion, effective utilization of process heat (e.g., for production of hydrogen), and intrinsic safety. The NGNP is to be designed, constructed, licensed and operating by no later than 2020, with a target date for initial operations of 2017 . Meeting these objectives will require technology stretch, but if the stretch is too great, the NGNP may become solely an exercise in research and development, and fail to accomplish the broader demonstration mission.

The ITGR reviewed several nuclear system concepts for a VHTR for the NGNP including the helium-cooled prismatic reactor, the helium-cooled pebble bed reactor, and the molten salt-cooled prismatic reactor. Results and recommendations of the review that are pertinent to structural design code development are summarized here:

- Few choices exist for metals for use at VHTR design conditions, and lifetime requirements may restrict the maximum operating temperature. The development of new materials (e.g., oxide dispersion strengthened or refractory metals, or ceramics and carbon-based materials) would not be compatible with construction time objectives.

- For high-temperature applications there are several undeveloped components, including the intermediate heat exchanger, the hot gas isolation valves, the reactor pressure vessel, selected reactor internals, the reactor inlet/outlet pipes, the helium circulator, the insulation systems, and instrumentation for high-temperature application.

- Definition of design basis conditions for a helium-cooled reactor system.

- Based on material development considerations, it is recommended that maximum metal temperature be limited to $900^{\circ} \mathrm{C}\left(1652^{\circ} \mathrm{F}\right)$. This corresponds to a maximum core average outlet temperature of $900-950^{\circ} \mathrm{C}$ $\left(1652-1742^{\circ} \mathrm{F}\right)$. Even at this metal temperature some reactor core subassemblies might require replacement during the 60-year design plant life. A reactor outlet temperature of $1000^{\circ} \mathrm{C}\left(1832^{\circ} \mathrm{F}\right)$ would require material development and testing well beyond the metals currently used in high-temperature design.

- It is recommended that the temperature of the irreplaceable primary reactor coolant pressure boundary be limited such that time-dependent (creep) deformation is insignificant. Creep deformation and configuration change would cause excessive uncertainty and risk over a 60 design life. 


\subsection{NGNP TECHNICAL ISSUES SAFETY RESEARCH NEEDS, June 2003 [23]}

This presentation provided an overall summary of research and application needs for licensing of the Next Generation Nuclear Plant (NGNP) Project. It includes safety R\&D arenas, licensing framework, probability risk assessment, nuclear analysis, thermal-fluid analysis, metallic components, nuclear graphite, fuel performance, qualification, fabrication, and testing.

Technical issues identified for metallic components that need resolution include:

- Fatigue, creep, and creep-fatigue interaction

- Coolant impurities and crevice concentration impacts

- Metal carburization, decarburization, and oxidation

- Sensitization of austenitic steels

- Alloy aging behavior at elevated temperatures

- Adequacy of in-service inspection plans and methods

- ASME code case and data base applicability/adequacy

- PRA failure probabilities for vessels, pipes, and components.

\subsection{FRAMEWORK FOR DEVELOPMENT OF A RISK-INFORMED, PERFORMANCE-BASED ALTERNATIVE TO 10 CFR PART 50, NUREG-1860, July 2006 [24]}

The purpose of this report is to document the technical basis to support the development of a risk-informed and performance-based process for the licensing of future nuclear power plants (NPP). As such it documents an approach, scope and criteria that could be used by the NRC staff to develop a set of regulations that would serve as an alternative to 10 CFR 50 for licensing future plants.

This report provides very broad guidance for safety review. It does not provide specific guidance for codes and standards because it is expected that most codes and standards will be associated with design-specific features. However, the evaluation approach described in this report relies heavily on Probabilistic Risk Assessment (PRA), which could have implications to high-temperature structural design codes. For example, the barrier integrity strategy provides isolation features that protect the primary radionuclide inventory from release. One feature is barrier structural integrity. PRAs are used to demonstrate that the frequency of radionuclide release is low enough, with adequate consideration of uncertainty. Therefore, uncertainties associated with barrier degradation, e.g., corrosion, erosion, aging, chemical interactions, and other materials issues need to be modeled. This does not necessarily imply that the structural design code must be based on PRA, but it appears that the code assessment results should be in a form that will allow PRA of barrier structural failure. 


\subsection{HOW REGULATORY ISSUES ARE ADDRESSED BY CURRENT ASME CODE CASES AND SECTION III SUBECTION NH "CLASS 1 COMPONENTS IN ELEVATED TEMPERATURE SERVICE."}

This section describes how the major issues cited by NRC as regulatory concerns are addressed in Subsection $\mathrm{NH}$ of the Code.

Subsection $\mathrm{NH}$ evolved from prior Code Cases originally intended for CRBR. The CRBR was designed to operate at temperatures in the range of $1000^{\circ} \mathrm{F}$ $\left(538^{\circ} \mathrm{C}\right)$ to $1100^{\circ} \mathrm{F}\left(593^{\circ} \mathrm{C}\right)$ with low pressure, relatively thin-walled sodium containing components - reactor vessel, tanks, piping, heat exchangers, steam generators, pumps, and valves. At these temperatures and loading conditions, the structural materials exhibited limited creep. As a result, it was possible to make extensive use of simplified analysis and bounding methods such as the O'Donnell-Porowski Bounds for creep ratcheting. The major thrust of the confirmatory programs was to insure that the effects of creep were bounded. Although a great deal of detailed inelastic analyses were performed, basically they were used to confirm the validity of simplified analysis methods for conditions dominated by cyclic thermal stresses.

While Subsection $\mathrm{NH}$ has evolved very substantially since CRBR, the design and operating conditions of VHTR and GEN IV systems are quite different. There are a number of different design concepts being considered and temperatures of interest are in the range of $1600^{\circ} \mathrm{F}\left(870^{\circ} \mathrm{C}\right)$ to $1700^{\circ} \mathrm{F}\left(925^{\circ} \mathrm{C}\right)$. Although there will be an effort to put the more highly stressed structural elements in cooler regions, the primary loads for many of the components will be higher than those encountered in CRBR. At these very high temperatures there will be a significant change in material behavior as well as structural response. Environmental effects will be more significant. Creep and the effects of creep on component integrity are expected to be limiting and will have to be analyzed in detail. Creep rupture damage, creep fatigue and potential creep crack growth are of particular concern. Material models will probably have to include tertiary creep as well as multiaxial states of stress. Although Subsection $\mathrm{NH}$ has the basic structure to handle elevated-temperature structural design, it will have to be extended and validated to handle the additional materials, higher temperatures, and creep damage mechanisms anticipated for these reactors.

\subsection{MATERIALS CREEP BEHAVIOR, CREEP FATIGUE AND ENVIRONMENTAL EFFECTS}

Section III, Subsection $\mathrm{NH}$ and the Code Cases for elevated-temperature design require further development to make them applicable for structural design and evaluation of HTGR and GEN IV systems. The temperature limits of code applicability need to be extended from $760^{\circ} \mathrm{C}\left(1400^{\circ} \mathrm{F}\right)$ to a maximum 


\section{Regulatory Safety Issues in the Structural Design Criteria of \\ ASME Section III Subsection NH for Very High \\ Temperatures for VHTR \& GEN IV}

Report

temperature up to $950^{\circ} \mathrm{C}\left(1742^{\circ} \mathrm{F}\right)$. The design lifetime limit of 34 years needs to be extended to 60 years. Subsection $\mathrm{NH}$ currently provides design limits for 5 materials up to $760^{\circ} \mathrm{C}\left(1400^{\circ} \mathrm{F}\right)$. Additional materials such as Alloy $617,9 \mathrm{Cr}-$ $1 \mathrm{Mo}-\mathrm{V}$ steel, and Hastelloy $X$ and Hastelloy $X R$ need to be added for temperatures up to $950^{\circ} \mathrm{C}\left(1742^{\circ} \mathrm{F}\right)$. Mitigating solutions are needed for environmental effects, including the degradation effects of impure helium. And the constitutive models for predicting inelastic and creep behavior of materials need to be developed. This must include the tertiary creep behavior immediately exhibited by alloy 617, and the cyclic creep behavior at operating temperatures.

NRC projects that its workforce size will need to grow from about 3,100 employees in early fiscal year 2006 to nearly 4,000 employees by 2010 to meet the significant anticipated upsurge in workload demands as NRC begins to review power company applications for permits to construct and operate new nuclear reactors (GAO-07-105). NRC also foresees the need for increased focus on Very High Temperature Reactor Licensing structural integrity issues not currently covered by the ASME Code and Code Cases, including:

- Materials behavior characterization for cyclic loads at very high temperatures

- Adequacy of structural analysis methods for cyclic loads at very high temperatures.

- Fatigue, creep, and creep-fatigue interaction

- Coolant impurities and crevice concentration impacts

- Metal carburization, decarburization, and oxidation

- Sensitization of austenitic steels

- Alloy aging behavior at elevated temperatures

\subsection{THE STRUCTURAL INTEGRITY OF WELDS}

The structural integrity of welds in elevated temperature service is a major regulatory concern requiring increased attention at elevated temperatures. Details of the regulatory concerns are described in Section 3.43 (1) "Weldment Cracking," herein. Subsection NH has rules for design of welded joints that are separated into categories A through $D$. The permissible types of welded joints and their dimensional requirements are described.

NRC has expressed concern for the potential for limited ductility of weldments at elevated temperatures and strain concentrations (both metallurgical and geometric) in the heat affected zones. Para. NH-3353 provides analysis requirements for the design and location of all pressure retaining and other primary structural welds subjected to metal temperatures where creep effects are significant. Special examination requirements are included for welded joints. Permissible weld materials are limited. Creep stress rupture reduction factors for weldments are given as a function of temperature and time. 


\section{Regulatory Safety Issues in the Structural Design Criteria of \\ ASME Section III Subsection NH for Very High \\ Temperatures for VHTR \& GEN IV \\ Report}

Subsection $\mathrm{NH}$ contains special limits on inelastic strains accumulated in the weld regions. These weld strain limits are one-half the strain values permitted for the parent material. The weldment strain limits are:

a. strains averaged through the thickness $=0.5 \%$

b. strains at the surface, due to an equivalent linear distribution of strain through the thickness $=1 \%$

c. maximum local strains at any point $=2.5 \%$

Subsection $\mathrm{NH}$ also reduces the allowable number of design cycles for weldments to one-half that of the parent metal. It reduces the allowable time for creep rupture damage by multiplying the stress by the weld strength reduction factor when determining the time-to-rupture.

Subsection $\mathrm{NH}$ also imposes additional examination requirements on category $\mathrm{A}$, $B, C$ and $D$ vessel weld joints.

The adequacy of these and other weldment structural design requirements in Subsection $\mathrm{NH}$ has been questioned by the NRC, even for the temperatures currently covered, which are lower than VHTR and Gen IV High Temperature Systems. Accordingly, Section 6.0 herein, which covers the materials models, design criteria and analysis methods needed in the ASME Code to cover regulatory issues for Very High Temperature Service, includes further discussion of these weldment issues.

\subsection{DEVELOPMENT AND VERIFICATION Of SIMPLIFIED DESIGN ANALYSIS METHODS}

The NRC sees the use of simplified methods of performing creep ratcheting, creep fatigue and creep rupture damage analyses, such as the O'DonnellPorowski Bounds, as a way of verifying the "black-box" of cyclic creep finite element analyses. The latter have not seen extensive safety related applications. Simplified methods are now used extensively in Subsection $\mathrm{NH}$. However, their derivation and verifications are based on simplifications and approximations such as thermal thru-wall stresses being essentially linear, bending stresses being essentially secondary, weldments having essentially homogenous properties, no metallurgical notches, and etc.

\subsection{VERIFICATION TESTING}

Because VHTR design analysis methods do not have a long history of successful application and require complex thermal cyclic finite element creep analysis, the NRC would like to see confirming tests verifying the materials models and structural features analyses. Cyclic materials models including strain hardening 
and time hardening require verification. Is primary creep repeated under cyclic load conditions, and is it recoverable? The cyclic behavior of representative key structural features is also an issue.

The Code does not explicitly require verification testing, but as an American National Standard Safety Code, the Code Committees have an obligation to meet the verification criteria thereof, and to satisfy NRC Licensing Safety Requirements in order to prevent the need for supplementary NRC Design Requirements.

\subsection{MATERIALS MODELS, DESIGN CRITERIA AND ANALYSES METHODS NEEDED IN THE ASME CODE TO COVER REGULATORY ISSUES FOR VERY HIGH TEMPERATURE SERVICE.}

NRC has prepared a current Draft for Review Table providing a List of Elevated Temperature Structural Integrity Issues. This table will update potential licensors of VHTRs and Gen IV Reactors to current NRC concerns. Please see Appendix $B$ herein.

\subsection{MATERIAL CREEP BEHAVIOR, CREEP FATIGUE AND ENVIRONMENTAL EFFECTS}

See Sections 4.3, 4.4, 4.5 and 3.6 herein for descriptions of current Code coverage of regulatory needs for very high temperature service. These needs are heavily materials-oriented and involve the Subcommittee on Materials (SCII), the Subcommittee on Nuclear Power (SCIII), Subcommittee on Pressure Vessels (SC-VIII) and Subcommittee on Design (SC-D). The Subgroup on Elevated Temperature Design is the focus group for these issues. In addition to these generic materials coverage Code needs, there are more specific needs related to weldments, the development and verification of simplified design methods, and test verification of materials models and representative structural features design analysis methods. These needs are discussed in the following sub-paragraphs.

\subsection{THE STRUCTURAL INTEGRITY OF WELDS}

Because of the importance of potential elevated temperature cracking of weldments, NRC wants the designer to account for potential creep strain concentrations due to metallurgical notch effects. Subsection $\mathrm{NH}$ does not include methods for analyzing the effects of varying properties between the base metal, weld metal and $H A Z$, or even how to determine these properties after welding and Post Weld Heat Treating. Moreover, NRC expressed concern with potential early crack initiation at the inside wall surface in the HAZ, how crack propagation can be quantified, and the stability of the remaining uncracked wall section. Methods of evaluating such weldment integrity issues and the 
corresponding safety margins are needed in the ASME Code to satisfy regulatory concerns. These methods will require materials models, cyclic creep analysis methods, crack growth analyses and remaining ligament enhanced creep stability analysis methods. Such methods essentially parallel Section XI flaw evaluation methods which are only applicable below the creep regime.

The NRC has also requested confirmation of the creep rupture, creep-fatigue, and interaction evaluation procedures at weldments, accounting for load sequence effects. These confirmations were required by ACRS before they would issue a plant operating license for CRBR, a matter that became mute when congress terminated this demonstration project.

The Subgroup on Elevated Temperature Design is the focus group responsible for these technical issues in the ASME Code. However, these issues also involve the Subcommittee on Nuclear Power (SC-III), the Subcommittee on Materials (SC-II), the Subcommittee on Welding (SC-IX), the Subcommittee on Pressure Vessels (SC-VIII), and the Subcommittee on Nondestructive Examination (SC-V).

\subsection{DEVELOPMENT AND VERIFICATION OF SIMPLIFIED DESIGN ANALYSIS METHODS}

Existing simplified design analysis methods have proven to be very valuable in providing assurance of structural integrity in the moderate creep regime and have been used in France, Germany, Japan, and the U.S. for this purpose. These methods can be further developed to include higher temperatures where creep effects control the design margins, and where structural discontinuity notches and defects need to be evaluated. Cyclic finite element creep analysis results are difficult to trust without having comparative results of simplified design analysis methods. These needs involve the Subcommittee on Nuclear Power (SC-III), the Subcommittee on Pressure Vessels (SC-VIII), and the Subcommittee on Design (SC-D), and are focused in the Subgroup on Elevated Temperature Design. The TF Elastic Plastic Finite Element Analyses could be expanded to include creep, the SG Design Analysis could verify and develop these rules, and/or the SG Elevated Temperature Design could reinstate their TF on creep analyses.

\subsection{VERIFICATION TESTING}

Verification testing was carried out on representative structural features of CRBR as part of the licensing effort. VHTR Temperatures are much higher than the CRBR temperatures, as previously discussed. Consequently, additional verification testing is desired by ACRS and NRC to validate the Elevated Temperature Designs of VHTRs. Such tests include validation of the material 
models needed to perform cyclic creep analyses, and validation of the finite element software capabilities to handle cyclic creep at structural discontinuities, elastic follow-up, creep rupture at notches, weldment behavior, and possibly flaw tolerance evaluation methods.

The development and delineation of such test needs comes under the purview of the Subgroup on Elevated Temperature Design. However, materials testing are generally in the domain of the Subcommittee on Materials (SC-II). The testing of nuclear power plant components is under Subcommittee III, and design adequacy comes under the Subcommittee on Design (SC-D). 


\section{Regulatory Safety Issues in the Structural Design Criteria of ASME Section III Subsection NH for Very High \\ Temperatures for VHTR \& GEN IV \\ Report}

\subsection{REFERENCES}

1. ASME Boiler and Pressure Vessel Code, Section III, Division 1 Subsection $\mathrm{NH}$, Class 1 Components in Elevated Temperature Design, 2004 Edition July 1, 2004, The American Society of Mechanical Engineers, New York, NY

2. ASME Boiler and Pressure Vessel Code Cases, Case N-47, Class 1 Components in Elevated Temperature Service, Section III, Division 1,American Society of Mechanical Engineers, New York, NY 1981

3. RDT Standard F9-5T, "Guidelines and Procedures for Design of Nuclear System Components at Elevated Temperature," September, 1974

4. C. E. Pugh, "Constitutive Equations for Creep Analysis of LMFBR Components," in Advances in Design for Elevated-Temperature Environment, Editors: S. Y. Zamrik and R. I. Jetter, ASME, New York, NY 1975

5. J. A. Clinard, and J. S. Crowell, ORNL User's Manual for CREEP-PLAST Computer Program, ORNL-TM-4062, November, 1973

6. W. K. Sartory, "PLACRE User's Manual," ORNL/TM-5626, February, 1977 (Availability: US DOE Technical Information Center)

7. Recommended Practices in Elevated-Temperature Design: A Compendium of Breeder Reactor Experiences (1970-1987), Volume III Inelastic Analysis, Edited by A. K. Dhalla, PVRC October 1990

8. D. S. Griffin, "Structural Analysis for Elevated-Temperature Design of the LMFBR," 1976 ASME-ANS International Conference on Advanced Nuclear Energy Systems, Pittsburgh, PA, March 1976, pp. 237-249

9. J. A. Clinard, et al, "Comparison of Typical Inelastic Analysis Predictions with Benchmark Problem Experimental Results," in Pressure Vessel and Piping - Verification and Qualification of Inelastic Analysis Computer Programs, Vessel and Piping, pp. 79-98, ASME, New York, NY 1975

10. D. S. Griffin, A. K. Dhalla, W. S. Woodward, "Validation of Inelastic Analysis by Full-Scale Component Testing", Journal of Pressure Vessel Technology, Volume 109, 1987, ASME, New York, NY

11. Safety Evaluation Report Related to the Construction of the Clinch River Breeder Reactor Plant, NUREG-0968, Vol. 1, Main Report, U. S. Nuclear Regulatory Commission, March 1983

12. D. S. Griffin, "Elevated-Temperature Structural Design Evaluation Issues in LMFBR Licensing, Nuclear Engineering and Design 90 , 1985, pp. 299306, North Holland, Amsterdam

13. A. K. Dhalla, and D. F. Rotoloni, "A Procedure to Incorporate Effects of Seismic Events in a Quasi-Static Piping System Inelastic Analysis, ASME Paper 82-PVP-28, 1982, ASME, New York, NY

14. A. K. Dhalla, "Verification of an Elastic Procedure to Estimate Elastic Follow-up in Design of Elevated-Temperature Piping," PVP Volume 86, 


\section{Regulatory Safety Issues in the Structural Design Criteria of ASME Section III Subsection NH for Very High \\ Temperatures for VHTR \& GEN IV \\ Report}

June 1984, pp.81-96, American Society of Mechanical Engineers, New York, NY

15. R. L. Huddleston and R. W. Swindeman, Material and Design Bases Issues in ASME Code Case N-47, NUREG/CR-5955 ORNL/TM-12266, Oak Ridge National Laboratory, April 1993

16. Preapplication Safety Evaluation Report for the Power Reactor Innovative Small Module (PRISM) Liquid-Metal Reactor, Final Report, Office of Nuclear Reactor Regulation, USNRC, February 1994

17. J. Muscara, "Codes and Standards Needs for New Construction/Advanced Reactors," presented at the Coordination Meeting - NRC, DOE, and Standards Development Organizations, February 20, 2002, Rockville, MD

18. J. Muscara, "Advanced Reactor Research Plan - Materials Analysis," presented for the ACRS Future Plant Designs Subcommittee, July 8, 2002, Rockville, MD

19. J. Muscara, "Interaction on Materials Engineering Research Needs for Advanced Reactors between USNRC/RES and ORNL, November 14, 2003, Oakridge, TN

20. V. N. Shaw, S. Majumdar, and K. Natesan, Review and Assessment of Codes and Procedures for HTGR Components, NUREG/CR-6816 (ANL02/36), Argonne National Laboratory, June 2003, prepared for the Office of Nuclear Regulatory Research, USNRC

21. K. Natesan, A. Purohit, and S. W. Tam, Materials Behavior in HTGR Environments, NUREG/CR-6824 (ANL-02/37), Argonne National Laboratory, July 2003, prepared for the Office of Nuclear Regulatory Research, USNRC

22. Design Features and Technology Uncertainties for the Next Generation Nuclear Plant, INEEL/EXT-04-01816, Independent Technology Review Group, Coordinator J. M. Ryskamp, Idaho National Engineering and Environmental Laboratory, June 30, 2004

23. S. D. Rubin, "NGNP Technical Issues Safety Research Needs," presented June 7, 2006, Office of Nuclear Regulatory Research, USNRC

24. Framework for Development of a Risk-Informed, Performance-Based Alternative to 10 CFR Part 50, NUREG-1860, Working Draft and Appendices, July 2006, Office of Nuclear Regulatory Research, USNRC

25. K. Natesan, S. Majumdar, P.S. Shankar, and V.N. Shah, Preliminary Materials Selection Issues for the Next Generation Nuclear Plant Reactor Pressure Vessel, ANL/EXT-06-45, September 2006, 


\section{APPENDIX A \\ NRC Licensing Review of CRBR - 1983 \\ List of Elevated Temperature Structural Integrity Issues}

Transition joints

Weld residual stresses

Design loading combinations

Creep-rupture and fatigue damage

Simplified bounds for creep ratcheting

Thermal striping

Creep-fatigue analysis of Class 2 and 3 piping

Are limits of Case $\mathrm{N}-253$ for elevated-temperature Class 2 and 3 components met?

Creep buckling under axial compression - design margins

Identify areas where Appendix T rules are not met

Rules for component supports at elevated-temperature

Strain and deformation limits at elevated-temperature

Evaluation of weldments

Material acceptance criteria for elevated-temperature

Creep-rupture damage due to forming and welding

Mass transfer effects

Environmental effects

Fracture toughness criteria

Thermal aging effects

Irradiation effects

Use of simplified bounding rules at discontinuities

Elastic follow-up

Design criteria for elevated-temperature core support structures and welds

Elevated-temperature data base for mechanical properties

Basis for leak-before-break at elevated temperatures 
Regulatory Safety Issues in the Structural Design Criteria of ASME Section III Subsection NH for Very High

Temperatures for VHTR \& GEN IV

Report

\begin{abstract}
APPENDIX B
Draft for Review: "Further Analysis of Appendix A "NRC Licensing Review of CRBR-1983 List of Elevated Temperature Structural Integrity Issues"
\end{abstract}


May 2, 2007

Draft for Review Further Analysis of Appendix A "NRC Licensing Review of CRBR-1983 List of Elevated Temperature Structural Integrity Issues" as Reported in the Final Report "Regulatory Safety Issues in the Structural Design Criteria of ASME.

\begin{tabular}{|c|c|c|c|c|c|}
\hline \multirow{2}{*}{$\begin{array}{l}\text { List of Elevated } \\
\text { Temperature Structural } \\
\text { Integrity Issues } \\
\text { (Issue as Given in } \\
\text { Appendix A) }\end{array}$} & \multicolumn{4}{|c|}{ Advanced Reactor Category } & \multirow[b]{2}{*}{$\begin{array}{l}\text { confirmed to be } \\
\text { pected concern) }\end{array}$} \\
\hline & CRBR & $\begin{array}{l}\text { PBR (\& } \\
\text { cold } \\
\text { vessel } \\
\text { option } \\
\text { for } \\
\text { VHTR) }\end{array}$ & $\begin{array}{l}\text { VHTR } \\
\text { (hot } \\
\text { vessel } \\
\text { option) }\end{array}$ & Gen-IV & \\
\hline 1. Transition joints & + & & + & + & $\begin{array}{l}\text { Improper joint design has been a concern in the field for Grade } \\
\text { P91 material modified Fe-9Cr-1Mo steel) joined to dissimilar } \\
\text { alloys (ANL/EXT-06-45, Sect. 3.2.3.5). The modified 9Cr-1Mo } \\
\text { steel is the primary/potential RPV candidate in several Gen IV } \\
\text { HTR programs and the Areva hot vessel concept. }\end{array}$ \\
\hline $\begin{array}{l}\text { 2. Weld residual } \\
\text { stresses }\end{array}$ & + & & + & + & $\begin{array}{l}\text { CRBR-related safety concerns are applicable to VHTR, Gen-IV. } \\
\text { (see ASME Task } 2 \text { report Section } 2.43 \text { [Concern 1]). } \\
\text { Evaluate potential for crack initiation at weldments due to } \\
\text { thermal fatigue, residual stresses, and damage caused by the } \\
\text { welding process. }\end{array}$ \\
\hline
\end{tabular}

\section{DRAFT for REVIEW DOES NOT NECESSARILY REFLECT ANY POSITION OF THE NRC}


Regulatory Safety Issues in the Structural Design Criteria of

ASME Section III Subsection NH for Very High

Temperatures for VHTR \& GEN IV

Report

May 2, 2007

Draft for Review Further Analysis of Appendix A "NRC Licensing Review of CRBR-1983 List of Elevated Temperature Structural Integrity Issues" as

Reported in the Final Report "Regulatory Safety Issues in the Structural Design Criteria of ASME.

\begin{tabular}{|c|c|c|c|c|c|}
\hline \multirow{2}{*}{$\begin{array}{l}\text { List of Elevated } \\
\text { Temperature Structural } \\
\text { Integrity Issues }\end{array}$} & \multicolumn{4}{|c|}{ Advanced Reactor Category } & \multirow{2}{*}{$\begin{array}{l}\text { Comments } \\
\text { cates issue confirmed to be of higher } \\
\text { concern; } \\
\text { a lower expected concern) }\end{array}$} \\
\hline & CRBR & $\begin{array}{l}\text { PBR (\& } \\
\text { cold } \\
\text { vessel } \\
\text { option } \\
\text { for } \\
\text { VHTR) }\end{array}$ & $\begin{array}{l}\text { VHTR } \\
\text { (hot } \\
\text { vessel } \\
\text { option) }\end{array}$ & Gen-IV & \\
\hline
\end{tabular}

DRAFT for REVIEW DOES NOT NECESSARILY REFLECT ANY POSITION OF THE NRC

O’Donnell Consulting Engineers, Inc. 
Regulatory Safety Issues in the Structural Design Criteria of

ASME Section III Subsection NH for Very High

Temperatures for VHTR \& GEN IV

Report

May 2, 2007

Draft for Review Further Analysis of Appendix A "NRC Licensing Review of CRBR-1983 List of Elevated Temperature Structural Integrity Issues" as

Reported in the Final Report "Reaulatorv Safetv Issues in the Structural Desian Criteria of ASME.

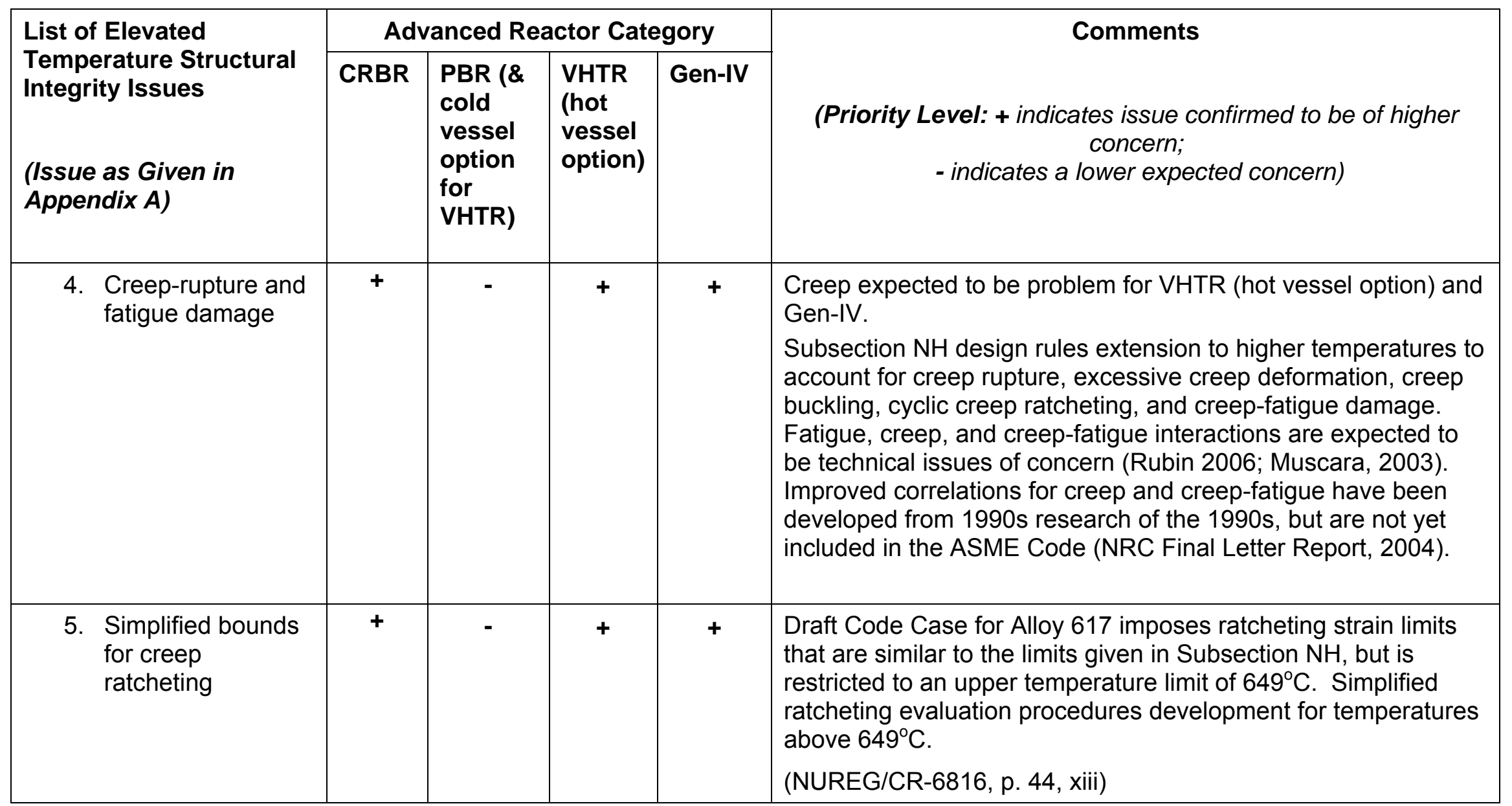

DRAFT for REVIEW DOES NOT NECESSARILY REFLECT ANY POSITION OF THE NRC

O’Donnell Consulting Engineers, Inc. 
Regulatory Safety Issues in the Structural Design Criteria of

ASME Section III Subsection NH for Very High

Temperatures for VHTR \& GEN IV

Report

May 2, 2007

Draft for Review Further Analysis of Appendix A "NRC Licensing Review of CRBR-1983 List of Elevated Temperature Structural Integrity Issues" as

Reported in the Final Report "Regulatory Safety Issues in the Structural Design Criteria of ASME.

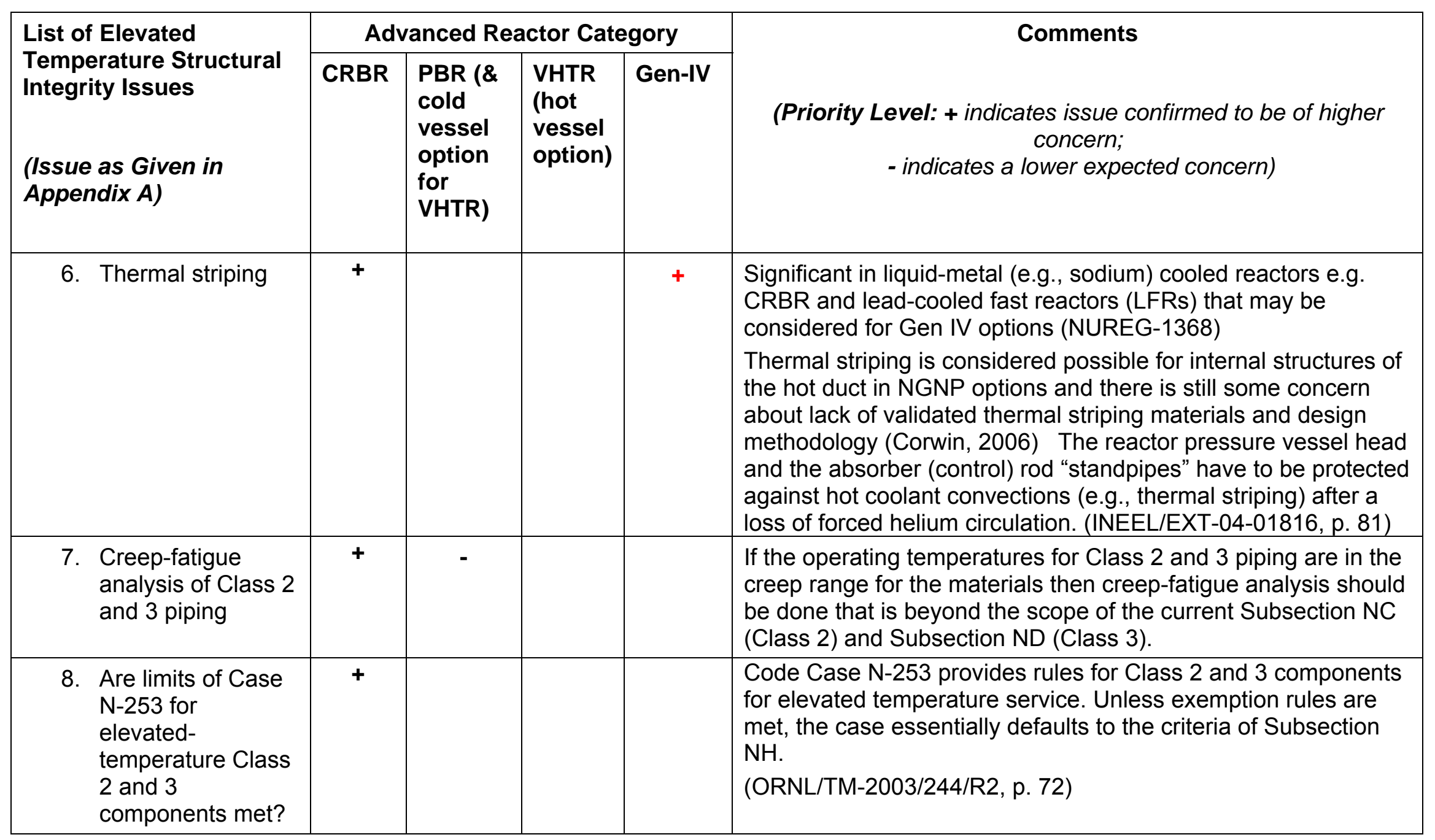

DRAFT for REVIEW DOES NOT NECESSARILY REFLECT ANY POSITION OF THE NRC

O’Donnell Consulting Engineers, Inc. 
Regulatory Safety Issues in the Structural Design Criteria of

ASME Section III Subsection NH for Very High

Temperatures for VHTR \& GEN IV

Report

May 2, 2007

Draft for Review Further Analysis of Appendix A "NRC Licensing Review of CRBR-1983 List of Elevated Temperature Structural Integrity Issues" as

Reported in the Final Report "Reaulatorv Safetv Issues in the Structural Desian Criteria of ASME.

\begin{tabular}{|c|c|c|c|c|c|}
\hline \multirow{2}{*}{$\begin{array}{l}\text { List of Elevated } \\
\text { Temperature Structural } \\
\text { Integrity Issues }\end{array}$} & \multicolumn{4}{|c|}{ Advanced Reactor Category } & \multirow[t]{2}{*}{ Comments } \\
\hline & CRBR & $\begin{array}{l}\text { PBR (\& } \\
\text { cold } \\
\text { vessel } \\
\text { option } \\
\text { for } \\
\text { VHTR) }\end{array}$ & $\begin{array}{l}\text { VHTR } \\
\text { (hot } \\
\text { vessel } \\
\text { option) }\end{array}$ & Gen-IV & \\
\hline $\begin{array}{l}\text { 9. Creep buckling } \\
\text { under axial } \\
\text { compression - } \\
\text { design margins }\end{array}$ & + & - & + & + & $\begin{array}{l}\text { Load controlled time-dependent creep buckling factors in } \\
\text { Appendix T (T-1522) to Subsection NH may need to be revised } \\
\text { for higher temperature expected in VHTR (hot vessel option) } \\
\text { and Gen-IV. }\end{array}$ \\
\hline $\begin{array}{l}\text { 10. Identify areas } \\
\text { where Appendix } \mathrm{T} \\
\text { rules are not met }\end{array}$ & + & - & + & + & $\begin{array}{l}\text { Appendix } \mathrm{T} \text { in } \mathrm{NH} \text { provides three expressions for determining } \\
\text { strain range. (ORNL/TM-2004/003). Modifications in Appendix } \\
\mathrm{T} \text { rules for higher temperatures and additional materials (e.g., } \\
\text { Alloy } 617 \text {, Hastelloy X/XR) may be needed. Appendix T rules } \\
\text { covers strain, deformation, creep and fatigue limits at elevated } \\
\text { temperatures for } 304 \mathrm{SS} / 316 \mathrm{SS}\left(816^{\circ} \mathrm{C}\right) \text {, Alloy } 800 \mathrm{H}\left(760^{\circ} \mathrm{C}\right), 2- \\
1 / 4 \mathrm{Cr}-1 \mathrm{Mo}\left(593^{\circ} \mathrm{C}\right), 9 \mathrm{Cr}-1 \mathrm{Mo}-\mathrm{V}\left(649^{\circ} \mathrm{C}\right)\end{array}$ \\
\hline $\begin{array}{l}\text { 11. Rules for } \\
\text { component } \\
\text { supports at } \\
\text { elevated- } \\
\text { temperature }\end{array}$ & + & & & & $\begin{array}{l}\text { NUREG-1338 referenced the } 1981 \text { version of NUREG-0800, } \\
\text { Section 3.9.3, "ASME Code Class 1, 2, and } 3 \text { Components, } \\
\text { Component Supports, and Core Support Structures." This was } \\
\text { revised in March } 2007 \text { to accommodate new reactors. } \\
\text { ASME Subsection NF rules on metal supports, may need to be } \\
\text { re-evaluated for use in VHTR and Gen-IV. } \\
\text { (Designed to transmit loads from the pressure retaining barrier } \\
\text { of the component of piping to the load carrying building } \\
\text { structure). }\end{array}$ \\
\hline
\end{tabular}

DRAFT for REVIEW DOES NOT NECESSARILY REFLECT ANY POSITION OF THE NRC

O'Donnell Consulting Engineers, Inc. 
Regulatory Safety Issues in the Structural Design Criteria of

ASME Section III Subsection NH for Very High

Temperatures for VHTR \& GEN IV

Report

May 2, 2007

Draft for Review Further Analysis of Appendix A "NRC Licensing Review of CRBR-1983 List of Elevated Temperature Structural Integrity Issues" as Reported in the Final Report "Requlatorv Safetv Issues in the Structural Desian Criteria of ASME

\begin{tabular}{|c|c|c|c|c|c|}
\hline \multirow{2}{*}{$\begin{array}{l}\text { List of Elevated } \\
\text { Temperature Structural } \\
\text { Integrity Issues }\end{array}$} & \multicolumn{4}{|c|}{ Advanced Reactor Category } & \multirow[t]{2}{*}{ Comments } \\
\hline & CRBR & $\begin{array}{l}\text { PBR (\& } \\
\text { cold } \\
\text { vessel } \\
\text { option } \\
\text { for } \\
\text { VHTR) }\end{array}$ & $\begin{array}{l}\text { VHTR } \\
\text { (hot } \\
\text { vessel } \\
\text { option) }\end{array}$ & Gen-IV & \\
\hline $\begin{array}{l}\text { 12. Strain and } \\
\text { deformation limits } \\
\text { at elevated- } \\
\text { temperature }\end{array}$ & + & - & + & + & $\begin{array}{l}\text { Issue } 10 \text { (on Appendix T rules) covers strain, deformation, creep } \\
\text { and fatigue limits at elevated temperatures. So, Issue 12, a } \\
\text { sub-set of Issue } 10 \text {, can be eliminated as a separate issue of } \\
\text { concern. Use of materials at high temperatures may result in } \\
\text { new deformation mechanisms (creep, creep-fatigue) becoming } \\
\text { issues. The extrapolation of time-dependent data where fatigue } \\
\text { is present represents a very significant challenge to the design. } \\
\text { (INEEL/EXT-04-01816, p. 47) }\end{array}$ \\
\hline $\begin{array}{l}\text { 13. Evaluation of } \\
\text { weldments }\end{array}$ & + & + & + & + & $\begin{array}{l}\text { CRBR-related safety concerns identified by NRC are applicable } \\
\text { to VHTR, Gen-IV. (see ASME Task } 2 \text { report Section } 2.43 \\
\text { [Concern 1]) The development of joining and design } \\
\text { methodologies are still considered important issues in } \\
\text { component construction and long-term performance (Corwin, } \\
\text { 2006) and concerns previously identified (Griffin, } 1985 \text { and } \\
\text { NUREG/CR-5955) for transition welds and lack of validated } \\
\text { weldment design methodology still remain. }\end{array}$ \\
\hline
\end{tabular}

DRAFT for REVIEW DOES NOT NECESSARILY REFLECT ANY POSITION OF THE NRC 
Regulatory Safety Issues in the Structural Design Criteria of

ASME Section III Subsection NH for Very High

Temperatures for VHTR \& GEN IV

Report

May 2, 2007

Draft for Review Further Analysis of Appendix A "NRC Licensing Review of CRBR-1983 List of Elevated Temperature Structural Integrity Issues" as Reported in the Final Report "Requlatorv Safetv Issues in the Structural Desian Criteria of ASME

\begin{tabular}{|c|c|c|c|c|c|}
\hline \multirow{2}{*}{$\begin{array}{l}\text { List of Elevated } \\
\text { Temperature Structural } \\
\text { Integrity Issues }\end{array}$} & \multicolumn{4}{|c|}{ Advanced Reactor Category } & \multirow[b]{2}{*}{ (Priority Level: + indica } \\
\hline & CRBR & $\begin{array}{l}\text { PBR (\& } \\
\text { cold } \\
\text { vessel } \\
\text { option } \\
\text { for } \\
\text { VHTR) }\end{array}$ & $\begin{array}{l}\text { VHTR } \\
\text { (hot } \\
\text { vessel } \\
\text { option) }\end{array}$ & Gen-IV & \\
\hline $\begin{array}{l}\text { 14. Material } \\
\text { acceptance criteria } \\
\text { for elevated- } \\
\text { temperature }\end{array}$ & + & & + & + & $\begin{array}{l}\text { May need to be re-evaluated for use in VHTR and Gen-IV. } \\
\text { Concerns about material property allowable design data/curves } \\
\text { for } 60 \text {-yr design life are still germane (Corwin, 2006) The target } \\
\text { design life of Gen IV components is generally } 60 \text { years ( } 526,000 \\
\text { h), which significantly exceeds life times currently allowed by } \\
\text { Subsection NH. The extension of the required data bases and } \\
\text { ASME Code acceptance of the materials for RPV service will } \\
\text { need to be developed and closely coordinated with the high- } \\
\text { temperature design methodology activities (ORNL/TM- } \\
2003 / 244 / R 2, \text { p. 55, 185) }\end{array}$ \\
\hline $\begin{array}{l}\text { 15. Creep-rupture } \\
\text { damage due to } \\
\text { forming and } \\
\text { welding }\end{array}$ & + & - & & & $\begin{array}{l}\text { Damage accumulation data are needed due to long-time high } \\
\text { temperature exposure. Particular attention is needed in the } \\
\text { area of welding to ensure that the issues of hot cracking and } \\
\text { premature creep failures in the heat-affected-zones of } \\
\text { ferritic/martensitic steels, observed in the fossil industry, are } \\
\text { adequately addressed. (ORNL/TM-2003/244/R2, p. 55) }\end{array}$ \\
\hline
\end{tabular}

DRAFT for REVIEW DOES NOT NECESSARILY REFLECT ANY POSITION OF THE NRC 
Regulatory Safety Issues in the Structural Design Criteria of

ASME Section III Subsection NH for Very High

Temperatures for VHTR \& GEN IV

Report

\section{May 2, 2007}

Draft for Review Further Analysis of Appendix A "NRC Licensing Review of CRBR-1983 List of Elevated Temperature Structural Integrity Issues" as Reported in the Final Report "Reaulatorv Safetv Issues in the Structural Desian Criteria of ASME.

\begin{tabular}{|c|c|c|c|c|c|}
\hline \multirow{2}{*}{$\begin{array}{l}\text { List of Elevated } \\
\text { Temperature Structural } \\
\text { Integrity Issues }\end{array}$} & \multicolumn{4}{|c|}{ Advanced Reactor Category } & \multirow[t]{2}{*}{ Comments } \\
\hline & CRBR & $\begin{array}{l}\text { PBR (\& } \\
\text { cold } \\
\text { vessel } \\
\text { option } \\
\text { for } \\
\text { VHTR) }\end{array}$ & $\begin{array}{l}\text { VHTR } \\
\text { (hot } \\
\text { vessel } \\
\text { option) }\end{array}$ & Gen-IV & \\
\hline $\begin{array}{l}\text { 16. Mass transfer } \\
\text { effects }\end{array}$ & + & - & - & + & $\begin{array}{l}\text { Thermal-gradient-induced mass transfer is significant in liquid- } \\
\text { metal (e.g., sodium or lead) cooled reactors e.g. CRBR and } \\
\text { LFRs. (ORNL/TM-2003/244/R2, p. 131); however it has not } \\
\text { been identified to be a major issue for PBR, or VHTR-HTR or } \\
\text { NGNP options. Weldment stress rupture factors should be } \\
\text { added to the draft ASME Code Case for Alloy } 617 \text { (NRC Final } \\
\text { Letter Report, 2004). }\end{array}$ \\
\hline $\begin{array}{l}\text { 17. Environmental } \\
\text { effects }\end{array}$ & + & + & + & + & $\begin{array}{l}\text { Environmental effects (e.g., impure helium leading to corrosion, } \\
\text { oxidation, and degradation on mechanical properties) need to } \\
\text { be considered in the failure criteria, particularly creep-fatigue. } \\
\text { Effect of helium coolant with impurities (oxygen) on reduction in } \\
\text { strength, fatigue life, and creep must be considered. The codes } \\
\text { and code cases do not provide specific guidelines for } \\
\text { environmental effects, especially the effect of impure helium, on } \\
\text { the high temperature behavior (e.g., creep and creep-fatigue) of } \\
\text { the materials considered. (NUREG/CR-6824, pg. 52, Muscara, } \\
\text { 2003; ORNL/TM-2003/244/R2, p. 72). More mechanistically } \\
\text { based predictive methods are needed to handle the various } \\
\text { material-specific damage mechanisms in different environments } \\
\text { (NUREG/CR-6816). Environmental degradation in general is of } \\
\text { concern and NUREG-1860 suggests the need to be able to } \\
\text { model uncertainties associated with barrier degradation. }\end{array}$ \\
\hline
\end{tabular}

DRAFT for REVIEW DOES NOT NECESSARILY REFLECT ANY POSITION OF THE NRC

O'Donnell Consulting Engineers, Inc. 
Regulatory Safety Issues in the Structural Design Criteria of

ASME Section III Subsection NH for Very High

Temperatures for VHTR \& GEN IV

Report

May 2, 2007

Draft for Review Further Analysis of Appendix A "NRC Licensing Review of CRBR-1983 List of Elevated Temperature Structural Integrity Issues" as Reported in the Final Report "Reaulatorv Safetv Issues in the Structural Desian Criteria of ASME.

\begin{tabular}{|c|c|c|c|c|c|}
\hline \multirow{2}{*}{$\begin{array}{l}\text { List of Elevated } \\
\text { Temperature Structural } \\
\text { Integrity Issues }\end{array}$} & \multicolumn{4}{|c|}{ Advanced Reactor Category } & \multirow[t]{2}{*}{ Comments } \\
\hline & CRBR & $\begin{array}{l}\text { PBR (\& } \\
\text { cold } \\
\text { vessel } \\
\text { option } \\
\text { for } \\
\text { VHTR) }\end{array}$ & $\begin{array}{l}\text { VHTR } \\
\text { (hot } \\
\text { vessel } \\
\text { option) }\end{array}$ & Gen-IV & \\
\hline $\begin{array}{l}\text { 18. Fracture } \\
\text { toughness criteria }\end{array}$ & + & & & & $\begin{array}{l}\text { Fracture mechanics analysis to justify the ability of the } \\
\text { component to withstand the expected service conditions, } \\
\text { especially when the component cools down to lower } \\
\text { temperatures leading to potential reduction in fracture } \\
\text { toughness ((NUREG/CR-6816) }\end{array}$ \\
\hline $\begin{array}{l}\text { 19. Thermal aging } \\
\text { effects }\end{array}$ & + & + & + & + & $\begin{array}{l}\text { The effects of thermal aging on mechanical properties and code } \\
\text { compliance over long term will be critical issues for each option } \\
\text { (ANL/EXT-06/45; Muscara 2003). Thermal aging and } \\
\text { sensitization is known for LWR temperatures but may be less } \\
\text { than expected lifetime at HTGR temperatures. } \\
\text { Furthermore, additional data are needed for the steel in the } \\
\text { areas of compatibility in impure helium and mechanical } \\
\text { properties of thick sections. }\end{array}$ \\
\hline
\end{tabular}

DRAFT for REVIEW DOES NOT NECESSARILY REFLECT ANY POSITION OF THE NRC

O'Donnell Consulting Engineers, Inc. 
Regulatory Safety Issues in the Structural Design Criteria of

ASME Section III Subsection NH for Very High

Temperatures for VHTR \& GEN IV

Report

May 2, 2007

Draft for Review Further Analysis of Appendix A "NRC Licensing Review of CRBR-1983 List of Elevated Temperature Structural Integrity Issues" as

Reported in the Final Report "Reaulatorv Safetv Issues in the Structural Desian Criteria of ASME.

\begin{tabular}{|c|c|c|c|c|c|}
\hline \multirow{2}{*}{$\begin{array}{l}\text { List of Elevated } \\
\text { Temperature Structural } \\
\text { Integrity Issues } \\
\text { (Issue as Given in } \\
\text { Appendix A) }\end{array}$} & \multicolumn{4}{|c|}{ Advanced Reactor Category } & \multirow[t]{2}{*}{ Comments } \\
\hline & CRBR & $\begin{array}{l}\text { PBR (\& } \\
\text { cold } \\
\text { vessel } \\
\text { option } \\
\text { for } \\
\text { VHTR) }\end{array}$ & $\begin{array}{l}\text { VHTR } \\
\text { (hot } \\
\text { vessel } \\
\text { option) }\end{array}$ & Gen-IV & \\
\hline $\begin{array}{l}\text { 21. Use of simplified } \\
\text { bounding rules at } \\
\text { discontinuities }\end{array}$ & + & + & + & + & $\begin{array}{l}\text { Current simplified inelastic methods and stress classification } \\
\text { techniques need to be assessed for very high temperature } \\
\text { applications, and improved or alternate approaches developed. } \\
\text { (ORNL/TM-2003/244/R2, p. } 72 \text { ) }\end{array}$ \\
\hline
\end{tabular}

DRAFT for REVIEW DOES NOT NECESSARILY REFLECT ANY POSITION OF THE NRC

O'Donnell Consulting Engineers, Inc. 
Regulatory Safety Issues in the Structural Design Criteria of

ASME Section III Subsection NH for Very High

Temperatures for VHTR \& GEN IV

Report

May 2, 2007

Draft for Review Further Analysis of Appendix A "NRC Licensing Review of CRBR-1983 List of Elevated Temperature Structural Integrity Issues" as

Reported in the Final Report "Reaulatorv Safetv Issues in the Structural Desian Criteria of ASME.

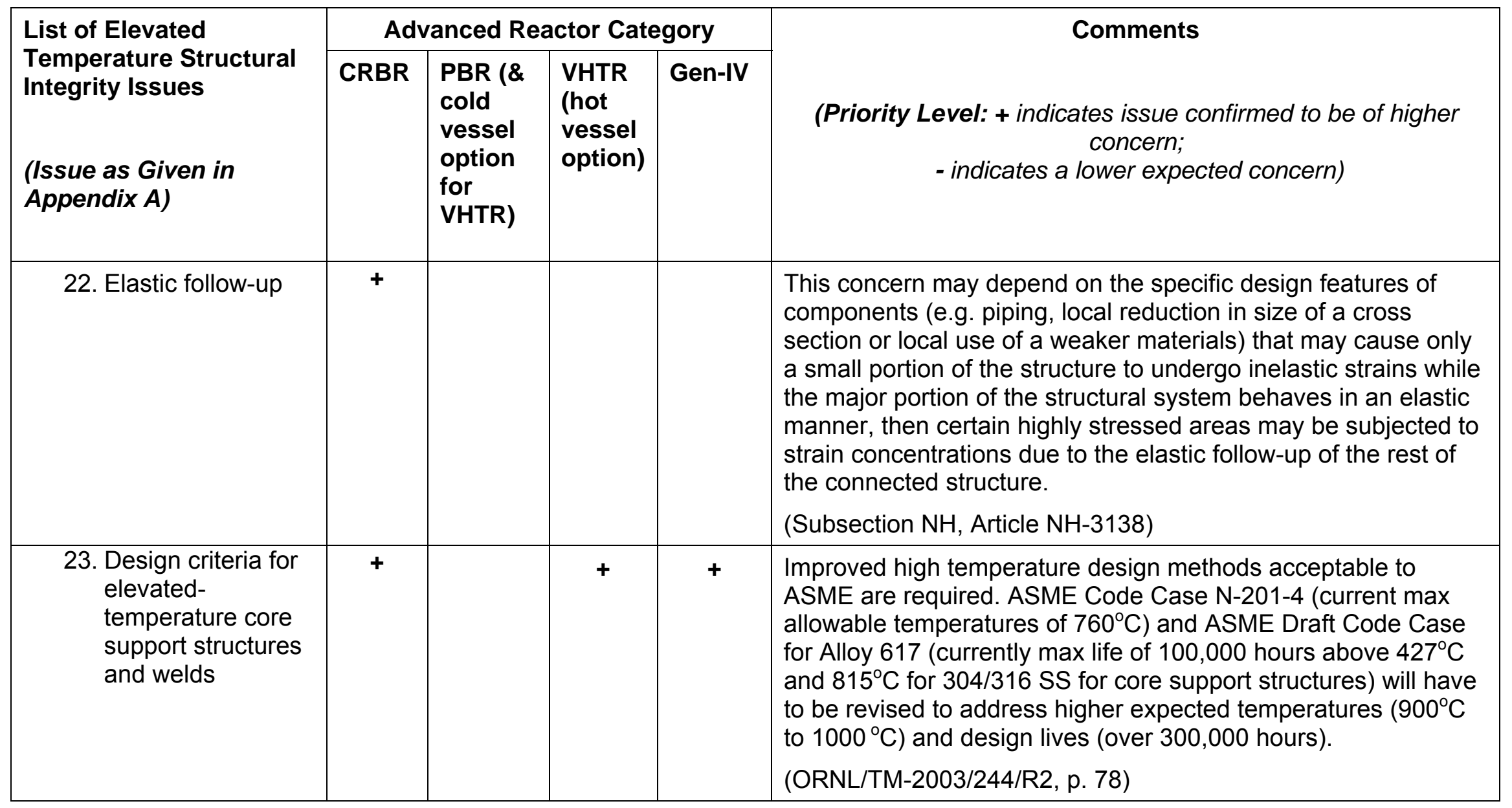

DRAFT for REVIEW DOES NOT NECESSARILY REFLECT ANY POSITION OF THE NRC

O'Donnell Consulting Engineers, Inc. 
Regulatory Safety Issues in the Structural Design Criteria of

ASME Section III Subsection NH for Very High

Temperatures for VHTR \& GEN IV

Report

May 2, 2007

Draft for Review Further Analysis of Appendix A "NRC Licensing Review of CRBR-1983 List of Elevated Temperature Structural Integrity Issues" as

Reported in the Final Report "Reaulatorv Safetv Issues in the Structural Desian Criteria of ASME.

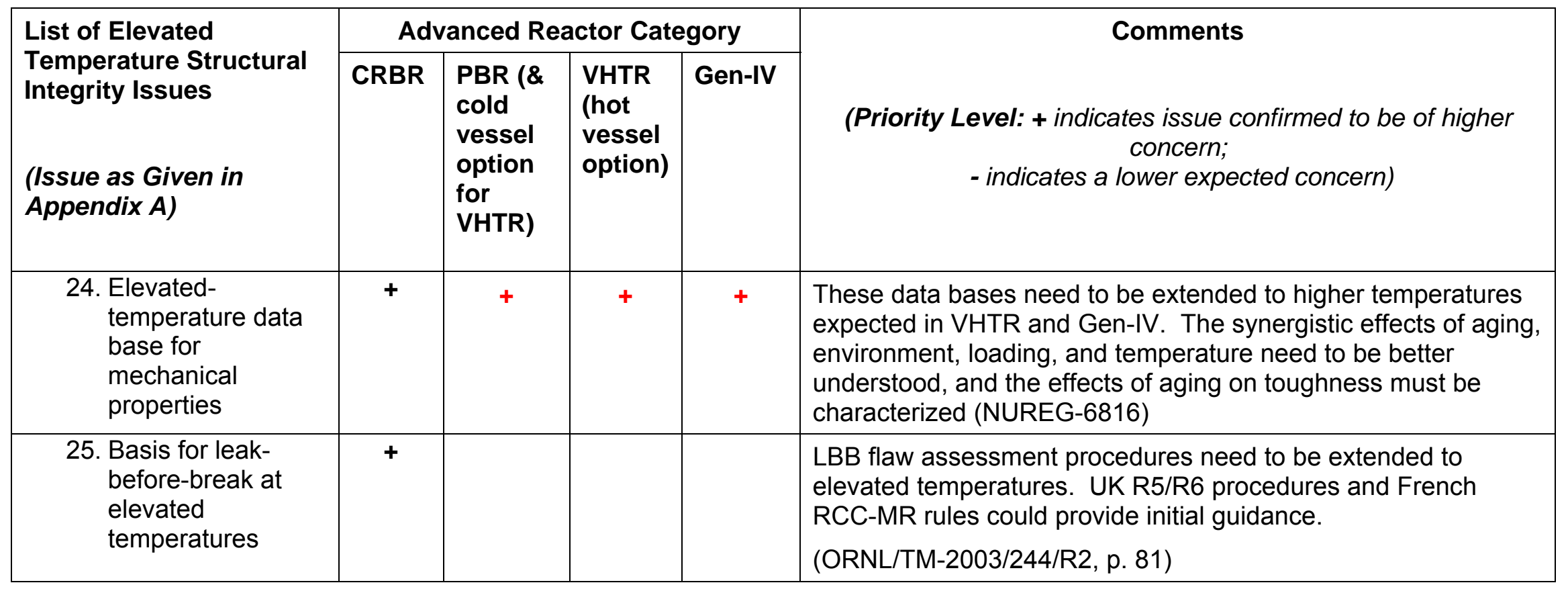

DRAFT for REVIEW DOES NOT NECESSARILY REFLECT ANY POSITION OF THE NRC

O'Donnell Consulting Engineers, Inc. 
Draft for Review Further Analysis of Appendix A "NRC Licensing Review of CRBR-1983 List of Elevated Temperature Structural Integrity

Issues" as Reported in the Final Rebort "Reaulatorv Safetv Issues in the Structural Desian Criteria of ASME.

\section{References:}

- ASME 2001. Boiler and Pressure Vessel Code, Sect. III, Subsection NH, Rules for Construction of Nuclear Facility Components, Class I Components in Elevated Temperature Service, Am. Soc. of Mechanical Engineers.

- ASME 2005. ASME Boiler and Pressure Vessel Code, Section III, Division 1- Subsection NH, Class 1 Components in Elevated Temperature Service, 2005 Addenda, July 1, 2005.

- Corwin, W.R., "U.S. Generation IV Reactor Integrated Materials Technology Program," Nuclear Engineering and Technology, Vol.38 No.7, October 2006, p. 591-618.

- Corwin, W.R., Timothy D. Burchell, William G. Halsey, George O. Hayner, Yutai Katoh, James W. Klett, Timothy E. McGreevy, Randy K. Nanstad, Weiju Ren, Lance L. Snead, Roger E. Stoller, Dane F. Wilson, "Updated Generation IV Reactors Integrated Materials Technology Program Plan Revision 2," ORNL/TM-2003/244/R2, 200 pp, December 2005.

- Griffin, D. S., "Elevated-Temperature Structural Design Evaluation Issues in LMFBR Licensing," Nuclear Engineering and Design, 90, 1985, pp. 299-306.

- Independent Technology Review Group, “ Design Features and Technology Uncertainties for the Next Generation Nuclear Plant, INEEL/EXT-04-01816, 100 pp, June 30, 2004

- Jetter, R.I., and T. E. McGreevy, "Simplified Design Criteria for Very High Temperature Applications in Generation IV Reactors," ORNL/TM-2004/308, 30 pp, December 2004.

- Muscara, J., "Materials Engineering Research Needs for Advanced Reactors," USNRC Powerpoint Presentation, Nov. 14, 2003.

- Natesan, K, A. Moisseytsev, S. Majumdar, P. S. Shankar, "Preliminary Materials Selection Issues for the Next Generation Nuclear Plant Reactor Pressure Vessel," ANL/EXT-06/45, 92pp, September 2006.

- NRC Final Letter Report, K. Natesan, S. Majumdar, W. K. Soppet, and D. L. Rink, "Evaluation of Metallic Components for High Temperature Gas Cooled Reactor (HTGR) Applications," 32 pp, June 2004.

- NUREG/CR-5955, Raymond Huddleston, R. and R. Swindeman, "Materials and Design Bases Issues in ASME Code Case N-47," ORNL/TM-12266, 33pp, April 1993.

- NUREG/CR-6816, Shah, V.N., S. Majumdar, K Natesan, "Review and Assessment of Codes and Procedures for HTGR Components," (ANL-02/36), 63pp, June 2003.

- NUREG/CR-6824, K Natesan, A. Purohit, S.W. Tam, "Materials Behavior in HTGR Environments," (ANL-02/37), 69pp, July 2003.

\section{DRAFT for REVIEW DOES NOT NECESSARILY REFLECT ANY POSITION OF THE NRC}


Regulatory Safety Issues in the Structural Design Criteria of

ASME Section III Subsection NH for Very High

Temperatures for VHTR \& GEN IV

Report

May 2, 2007

Draft for Review Further Analysis of Appendix A "NRC Licensing Review of CRBR-1983 List of Elevated Temperature Structural Integrity

Issues" as Reported in the Final Report "Reaulatorv Safetv Issues in the Structural Desian Criteria of ASME.

- NUREG-0800, Standard Review Plan for the Review of Safety Analysis Reports for Nuclear Power Plants, Chapter 3, Design of Structures, Components, Equipment, and Systems, Section 3.8.2 "Steel Containment," 28pp, Revised March 2007.

- NUREG-1338, "Preapplication Safety Evaluation Report for the Modular High-Temperature Gas-Cooled Reactor (MHTGR)," 225pp, December 1995.

- NUREG-1368, "Preapplication Safety Evaluation Report for the Power Reactor Innovative Small Module (PRISM) Liquid-Metal Reactor," 444pp, February 1994.

- NUREG-1860, "Framework for Development of a Risk-Informed, Performance-Based Alternative to 10 CFR Part 50, Working Draft,"167 pp, July 2006.

- Regulatory Guide 1.57, Design Limits and Loading Combinations for Metal Primary Reactor Containment System Components, Revised March 2007.

Rubin, S., "NGNP Technical Issues Safety Research Needs," USNRC Powerpoint Presentation, ADAMS ML061730419, June 7, 